
\title{
$\angle$ Research Soure \\ Identification of Isosteric Replacements of Glycosyl Domain of Ligands by Data Mining
}

Ting Li

Northwestern Polytechnical University https://orcid.org/0000-0002-9028-0362

Meng Liu

Northwestern Polytechnical University https://orcid.org/0000-0001-6603-8747

Yan Liu

Northwestern Polytechnical University https://orcid.org/0000-0002-4474-797X

Yuezhou Zhang ( $\square$ iamyzzhang@nwpu.edu.cn )

Northwestern Polytechnical University https://orcid.org/0000-0002-8560-5716

\section{Research Article}

Keywords: local structural replacements, cheminformatics workflows, ribose, molecular interactions, PDB mining

Posted Date: November 23rd, 2021

DOI: https://doi.org/10.21203/rs.3.rs-955132/v1

License: (우 (i) This work is licensed under a Creative Commons Attribution 4.0 International License. Read Full License 


\section{Abstract}

Biologically equivalent replacements of key moieties in molecule rationalizes scaffold hopping, patent busting or R-group enumeration, yet heavily depending upon the expert-defined space therefore is subjective and might be biased to the chemistries they get used to. Most importantly, these explorations are often informatively incomplete since it is often confined within try-and-error cycle, only meaning what kind of substructures are suitable for the replacement occur, but fail to disclose the driving forces to support such interchanges. The Protein Data Bank (PDB) repository involving receptor-ligand interactional information reminds poorly exploited. However, manual screening the PDB become almost impossible to excavate the bioisosteric know-how with the exponentially increase of data. Therefore, a textual content parsing workflow is developed to automatedly mine local structural replacement (LSR) of specific structure. Taking the glycosyl domain for instance, a total of 41652 replacements that overlap on nucleotide ribose were identified and categorized based on their SMILE codes. Predominately ring system, such as aliphatic aromatic ring, yet amide and sulfonamide replacement also occurred. We believe these findings may enlighten medicinal chemists to design and optimize ligand structure using bioisosteric replacement strategy.

\section{Introduction}

Medicinal chemists are always keen to improve the potency of small-molecule toward their biological targets using variety of computational approaches, exemplified by high-throughput screening, quantitative structureactivity relationship and fragment-based drug design, but the successful rate of drug discovery project remain low[1] and identification of potent compounds is expensive. However, it is often observed that some biomacromolecules accommodate endogenous ligands (EL) with high affinity. Meanwhile minor modification of EL may trigger massive activity cliff and can be readily accepted by the live organism given their structural intimacy. Therefore, reassemble of EL skeleton using partial structural replacement/exchange strategy is often under consideration to optimise the pharmacodynamics properties of the leads or coin new drug candidates. Although handful of means to obtain these chemical building blocks are available, bioisosteric transformation is among prioritised hierarchy thanks to its faithful identity in terms of molecular recognition[2]. Bioisosteric information could be attained either by applying medicinal chemistry knowledge or by mining databases.

In the early stage, the obtainment of bioisosteres heavily depend on the experience of practitioner, which possibly confined the application of bioisosterism since a novice chemist hardly know the proper replacements of specific fragment, and even the most experienced medicinal chemists may become during their careers unfamiliar with the ever-increasing chemical knowledge. There is no doubt the bioisosteres of reference fragment can be fished out from massive published literature, yet it could offer a group of possible bioisosteric alternatives (what or who), but often fail to explain the mechanism (how or why) related to the replacements. The fundamental of isosteric transformability comes from interaction loyalty of among bioisosteres whose mechanism-of-action drug targets[3], mainly variety of proteins, is the same or the-site-ofaction remains identical. The molecular interaction information can be measured through experimental means such as isothermal titration calorimetry, while detailed insights can be observed by structural methods, exemplified by X-ray crystallography, a general the method of choice to obtain three-dimensional structures of the bound ligand/protein complex. The obtained information is often deposited into open database and saved 
as computer readable files, therefore facilitate the digitalized compilation of bioisosteric replacements. ChEMBL[4] is freely accessible database of more than 1.9 million small molecules with bioassay data curated from literature. BIOSTER, for example, contains bioisosteric transformations collected from medicinal chemistry literature published during past 4 decades. Based on these data and the Matched Molecular Pair (MMP) approach, molecules in ChEMBL that display bioisosteric features are identified, which also allows for the leverage of potential changes in biological properties with bioisosteric transformation; the above-mentioned information were currently presented as SwissBioisostere database for both non-commercial and commercial users[5]. Spark ${ }^{\text {Tm}}$ (Cresset, UK)[6] screens a database of more than 600,000 fragments to pinpoint bioisosteres that display similar steric and electronic features as the interest domain of molecules. Recently, bioisosteric analogs are identified by a deep neural network trained on a large corpus of experimentally validated analogs extracted from medicinal chemistry knowledge accumulated in nearly fifty years efforts[7].

Rapidly growing openly accessible structural databases, including The Cambridge Structural Database (CSD)[8, 9]and Protein Data Bank (PDB)[10] enable another opportunity to obtain new bioisosteric replacements in more automatic and robust manner. Through data mining and informatic curation[11], massive valuable bioisosteric know-how related with drug discovery and development can be disclosed. Frank et al[12] used crystal structure information from the CSD to inclusively study the geometrical and energetic aspects of the tetrazole-carboxylic acid bioisosterism by comparison of the conformational preferences and intermolecular interactions. After superimposition of holo proteins in the PDB with a reference protein, fragments reside in the same binding site are considered as potential bioisosteric candidates[13]. Following the similar idea, the query and the reference ligands complexed with the same protein were fragmented into a set of fragments and compared each other by their volume overlap, the pair with score higher than a given threshold forms a bioisosteric peer[14]. Further on, the similarity of binding site subpocket is quantified based on pharmacophore fingerprints, hence enables the both intra- and inter-family comparisons of proteins for bioisosteric replacements for ligand substructures[15]. FragVLib[16], a virtual library of fragments, allows for bioisosteric replacements identification based on a subgraph matching tool that finds similar binding pockets according to their $3 \mathrm{D}$ structures and chemical similarity of the atoms. Desaphy et al developed Sc-PDB-Frag[17] that implements bioisosteric searches by converting protein-ligand interaction patterns to graphs; bioisosteres are defined as any pair of ligands that share similar interaction patterns with their reference protein.

On the other hand, it is often difficult for non-computer science background ones to obtain such information, so as to refer to drug design and lead optimization. Therefore, the effort toward user-friendly web servers that does not require computational or programming skills but is favourable to medicinal chemists to quickly search and get new ideas about possible bioisosteric replacements have been released. For instance, BoBER[18] identified bioisosteric replacements using local binding site; ProBiS-ligands[19] sought for similar local spatial arrangements of physiochemically similar surface functional groups in binding sites; taking liganded structure as an input and choosing specific substructures want to replace, FragRep try to find suitable bioisosteric fragments that where the structure is different, while interaction patterns with the protein pocket are similar[20].

Ribose (a naturally occurring pentose sugar), commonly seen as D-ribose, is indispensable components of nucleotides and primarily for the assembly of RNA in all living organisms[21]. It is also part of Riboflavin (vitamin B2)[22], adenosine triphosphate (ATP). Closely related sugar 2-deoxyribose is the building block of DNA[23]. ADP and AMP, the metabolites of ATP, are more stable and are common represented in macromolecule 
complex as endogenous ligands. The ribose containing molecules play critical pharmacology roles, for example, ADP ribose is a specific agonist of the purinergic $\mathrm{P} 2 \mathrm{Y} 1$ receptor[24], leading to $\mathrm{Ca}^{2+}$ mobilization in rat pulmonary arterial smooth muscle cell[25]. Cyclic ADP-ribose and NAADP function as $\mathrm{Ca}^{2+}$ messengers and $\mathrm{Ca}^{2+}$ stores[26] in cells. Chemically, ribose is a five-member ring fragment composed of four carbon and one oxygen atoms. Three of the carbons attached to hydroxyl groups (1'-, 2'- and 3'-). The fourth carbon attached to the fifth carbon atom connecting a hydroxyl group (5'-). Intuitively, hydroxyl-rich structure makes ribose itself hydrophilic. In practice, 1'- and 5'- hydroxyl of ribose are normally substituted or replaced by hydrophobic moieties.

Isosteric replacement of ribose groups is a classic practice in medicinal chemistry. For example, the modification of ribose of nucleosides, has led to the discovery of several drugs (Figure 1): such as cancer therapeutics Floxuridine (FUdR, 5-fluoro-2-deoxyuridine) [27] where the 2'-hydroxyl of 5-fluoro-uridine is absent. Cytarabine (Ara-C) is a stereoisomer of cytidine with the D-ribose[28], replaced with D-arabinose. Antivirals such as Vidarabine (Ara-A)[29] combined an adenine base and a D-arabinose sugar and acyclovir host a truncated ribose structure comparing to guanosine. Zidovudine, or azidothymidine[30] has the 3'-hydroxyl replaced by azido moiety. Other nucleoside analogues involved in inhibition of HIV-1 reverse transcriptase, including Didanosine[31] and Zalcitabine[32] whose 2'- and 3'-hydroxyl of ribose are totally deleted. Blocking the puckering Zalcitabine deoxyribose ring by introducing a double bond between 2'- and 3'-carbon gave rise to another HIV-1 reverse transcriptase inhibitor Stavudine[33]. The systematic structure-activity relationship investigation of nucleoside glycosyl domain also suggested the modification of ribose is a promising method toward successful drug development[34]. The above-mentioned attempts can be thought as nucleosides in which the nitrogenous bases are attached to unnaturally occurred ribose via a beta-N(1)-glycosidic bond and ribose fragment undergoes either stereoisomerism, hydroxyl truncation and chemical modification, but nearly experience the scaffold change. Hence, brand-new ribose isosteres/bioisosteres are highly desired to generate new analogues with improved properties.

Another endogenous ligand that underwent considerable modification of ribose[35] is cyclic ADP-ribose (CADPR), a signalling molecule that has been shown to regulate $\mathrm{Ca}^{2+}$ mobilization intracellularly. cADPR consist of two ribose, namely "northern" and "southern" one[36]. The modification of cADPR ribose has led to a few chemical entities with useful pharmacology properties. For example, cyclic aristeromycin diphosphoribose(cArisDPR), featured the furanose oxygen in "southern" ribose replaced by methylene, was a hydrolysis resistant agonist; with the half-lives improved from 15 minutes of cADPR to 170 minutes of cArisDPR when it is incubated in sea urchin egg homogenates[37]. However, 3'-0-methyl-cADPR based on "southern" ribose substation became an antagonist of cADPR induced $\mathrm{Ca}^{2+}$ release[38]. "Southern" ribose appeared nonessential for the binding of CADPR to the human ADP-ribosyl cyclase CD38 catalytic domain since the replacement of the $N 9$-ribose with a butyl chain generates an analogs which inhibited the hydrolysis of CADPR[39]. Similarly, the substitution of "northern" ribose by different alkene chain led to several cADPR analogues who were able to permeate in intact human Jurkat T-lymphocytes and act as agonists[40]. 2'- $\mathrm{NH}_{2}$ ' cADPR, with an amino group replacing the 2'-hydroxyl group of cADPR in the "northern" ribose, was an agonist in the T-lymphocyte system with the $\mathrm{EC}_{50}$ of $7 \mu \mathrm{M}$ as compared to $13 \mu \mathrm{M}$ of cADPR[41] and hydrolyzed nearly 100-fold slower than cADPR[42]. Other analogues of cADPR, cyclic ADP-4-thioribose, in which the "northern" ribose of CADPR was replaced by a 4-thioribose was completely resistant in rat brain microsomal extract and 
induced the release of $\mathrm{Ca}^{2+}$ ions in a concentration-dependent manner with an $\mathrm{EC}_{50}$ value of $36 \mathrm{nM}$ in sea urchin egg homogenate testing, while cADPR and CADPcR gave the $\mathrm{EC}_{50}$ value of 214 and $54 \mathrm{nM}$, respectively[43].

The substitution of the ribose often occurred in 2'- and 3'-position where the number of both hydrogen bond donors and acceptors are reduced, which is also important for cell permeability, especially for ligands targeting to central nervous system (CNS). For example, the polarity of 4-nitrobenzylthioinosine reduced by replacing ribose moiety with substituted (aryl)benzyl group. These chemical properties very different replacement led to two equally active analogues with Kivalue of $39 \mathrm{nM}$ but 101 and $85 \AA^{2}$ of polar surface area (PSA) individually[44], a significant decrease comparing to PSA of $154 \AA^{2}$ of parent compounds. In some cases, the ribose moiety is not important for the binding, replacement the ribosyl group with a hydrophobic group might be rational because the polar hydroxyl groups of the ribose moiety are entropically unfavourable (require higher desolvation energy) but have no contribution to binding affinity. For instance, the change of ribose moiety in compound $1.6\left(\mathrm{IC}_{50}, 100 \mathrm{mM}\right)$ with benzyl compound $\left(\mathrm{IC}_{50}, 91 \mathrm{mM}\right)$ showed better potency[45]. If structurebased drug design or other computer tools suggest that the hydrogen bonds between ribosyl hydroxyl and protein residues contributed little to the overall binding affinity[46], while hydrophobicity dominated binding pocket prefer the hydrophobic moiety, then the replacement of ribose with a alkyl group should be placed. For example, cyclohexylethyl group replacement $\left(\mathrm{IC}_{50}, 97 \mathrm{mM}\right)$ of ribose $\left(\mathrm{IC}_{50}, 118 \mathrm{mM}\right)$ lead to comparable potency compound that minimize desolvation costs and gain van der Waals interactions with fructose 1,6bisphosphatase[47]. In the process of investigation adenosine 5'-diphosphoribose (ADPR) to modulate transient receptor potential melastatin 2 channel, it was found that replacing the terminal ribose of ADPR with a cyclopentyl group resulted in a weak antagonistis yet but remain attractive because the anomeric center stereochemistrys was removed, which negates the possibility of intramolecular interaction between the pyrophosphate and a ribose hydroxyl group, and therefore may lead to instability[48].

Although considerable ribose modification/replacement protocols have been elaborated for variety of applications, few of them specifically address the necessity ribose replacement from molecular interactions perspective, meaning the identification of proper ribose bioisosteres remain the trial-and-error circle. Given the importance the bioisosterism in contemporary medicinal chemistry practice[49] and wide application[50, 51], for the first time, we have developed a cheminformatics workflow to mine the PDB for isosteric replacements of biologically important phosphate[52]. Besides the classical isosteres of phosphate, such as carboxylate, sulfone or sulfonamide[53], unexpected replacements that do not conserve charge or polarity, such as aryl, aliphatic, or positively charged groups were found. The disclosed results were timely applied for online computational tools development[54], cheminformatics refinement[55], probe ligands[56] and Plasmodium falciparum pyrophosphatase inhibitors[57] synthesis, demonstrated the necessity and demand of phosphate replacement in drug development streamline. The data mining workflow we previously presented could be generalized to exploit structural isosteres of any chemical fragments interested. Ideally, the query group could be defined by the user and the workflow could automatically select the proper reference compounds for data extraction. In this study, we aim not only to identify the possible structural replacements of ribose moiety, but understand the mechanism which drive the occurrence of replacements specifically from molecular recognition perspective.

\section{Methods}


We relied on five external programs to implement the workflow (Figure 2A): Blastp compares the query protein sequences to sequence of PDB and outputs protein homologues with predefined the statistical

significance; TM-align generates optimized residue-to-residue alignment of two protein structures and supply optimal superposition of the them; ShaEP calculates the fitness of overlaid molecular fragments; Babel translate the extracted molecular fragment into SMILES string; and EMBOSS Needle implements global pairwise sequence alignment. Having these tools complied and integrated with Python scripts, the workflow firstly retrieves from PDB the three-dimensional structures of protein that homologize with protein bound with a nucleotide designated as "reference ligands". For the protein with multiple identical chains, only single representative one is kept and append PDB code_chain identifier as output name. Secondly, the work flow acquires and aligns homologues of each reference protein and preserves target proteins with a non-nucleotide ligand bound at identical site of the reference ligand. Those with no ligand atom at the structural isostere site are removed. Thirdly, local structural replacements are extracted based on sphere whose centre defined by 02', 03' and 04' atoms of nucleotide, setting radius of $2.5 \AA$. Lastly, the fragments are categorized according to equivalent SMILES codes into 16 exclusive groups; cycle group is complex and tedious, therefore further decomposed into 15 subgroups for clarity.

The empirically optimized filters used for the run which is presented are as follows: PDB data with resolutions lower than $2.7 \AA$ is excluded; homologues were interrogated by a BlastP e-value of $10^{-100}$; manually built list of prefiltered compounds AMP, ADP, ATP, POP, ANP, TTP, DCP, DGT, DTP, DUP, ACP, AD9, NAD, AGS, APC, AOV, U5P, UDP, UTP , 5GP, GDP, GTP, C5P, CDP and CTP in the pool of target ligands are excluded; binding site was defined as any amino acid with at least one atom within $4.5 \AA$ of the bound reference ligand; a Shape component cut-off calculated by ShaEP higher than 0.2 was required.

\section{Results And Discussion}

\section{Data Curation}

The prototype of data organization, SMILES-based folders and contents of the running presented are almost identical to already published by us[52], but several features are mended: The scripts, previously written in Python2.7, are rephrased according to the syntax of Python3.6 and made accessible through the GitHub collaborative code sharing platform at https://github.com/Yuezhou-Project/Isoldentifier; An updated version of the PDB database of June 2020 release (145600 structural deposition) are used; NMR entries are excluded; Nucleotide-binding proteins, i.e., proteins bound to not only AMP, ADP, ATP but also U5P, UDP UTP, C5P, CDP, CTP, 5GP, GDP GTP are used as examples. The workflow (Figure 2A) provides the user with analysis figures plotted in real-time through interfacing with the $\mathrm{R}$ package. The workflow is applied to search the replacements of ribose moieties of these reference proteins (Table 1). In total 2734 reference proteins and 40929 local structural replacements are identified. The bias of these data concerning different nucleotides, for instance 759 cases of ADP binding protein versus only 24 cases of CDP, reflects the massive crystallographic and drug development project to purine over pyrimidine derivatives (Table 1).

\section{Table 1. Number of Complexes and Ligands Collected in Each of the Datasets}


Number of structural isosteres in data set, after ShaEP filter

\begin{tabular}{lllllll}
\hline & $\begin{array}{l}\text { reference } \\
\text { complexes } \\
\text { in PDB }\end{array}$ & $\begin{array}{l}\text { references } \\
\text { complexes }\end{array}$ & $\begin{array}{l}\text { Total } \\
\text { (isostere- } \\
\text { containing } \\
\text { empty) }\end{array}$ & $\begin{array}{l}\text { total(isostere- } \\
\text { containing) }\end{array}$ & $\begin{array}{l}\text { with binding } \\
\text { sites identical } \\
\text { to reference } \\
\text { protein }\end{array}$ & ribose \\
\hline AMP & 653 & 333 & 7393 & 4085 & 773 & 2826 \\
\hline ADP & 2148 & 759 & 19633 & 17858 & 2239 & 13281 \\
\hline ATP & 1312 & 563 & 19111 & 12655 & 1639 & 9438 \\
\hline U5P & 91 & 53 & 577 & 917 & 248 & 711 \\
\hline UDP & 415 & 187 & 3476 & 1707 & 383 & 1544 \\
\hline UTP & 70 & 36 & 1115 & 489 & 156 & 368 \\
\hline C5P & 86 & 40 & 211 & 249 & 102 & 219 \\
\hline CDP & 53 & 24 & 373 & 242 & 114 & 187 \\
\hline CTP & 124 & 49 & 1303 & 968 & 153 & 838 \\
\hline 5GP & 121 & 56 & 390 & 389 & 121 & 275 \\
\hline GDP & 1101 & 458 & 5884 & 9268 & 968 & 8644 \\
\hline GTP & 765 & 176 & 4137 & 2946 & 338 & 2598
\end{tabular}

The substructures extracted are hierarchically organized (Figure 2B) according to a decomposition SMILES code and the hierarchy is given as a text file (Supporting Information 1). The results are also archived into folder and downloadable, composed of structure files in pdb format and organized hierarchically into folders (Supporting Information 2). These data can be visualized by using computational tools, such as PyMol[58]. Herein, 23 examples are discussed. The ligand-receptor recognition patterns of these examples are extrapolated in detail. In addition, the structure-activity relationship (SAR) of them is also appreciated if the data are available. For each of them a diagram of ligand interaction is provided (Supporting Information 3) by LigPlot+[59]. Of these examples, 13 are of high resolution, better than $2.3 \AA$, among which 7 have been solved at a resolution better than $2.0 \AA$ (resolution of the 18 examples as well as characteristics of the ligands, Supporting Information 4, Table 1).

To focus on the ribose replacements of most interest while put aside many uninteresting or nearly identical ones, and ignore the very small replacements (Supporting Information 5) containing fewer than three atoms, a classification SMILES code-oriented paradigm is proposed for the extracted fragments with a structural fit on ribose groups. The same folder naming rules is followed as previously. The largest and complex folder is cycle one, it is reasonable since ribose itself is ring-based structure. This folder, therefore is further divided into subfolders, and nominated as cycle.*, herein * stands for the specific atom included in the extracted ring fragments. For instance, cycle.S means the extracted substructures in this folder contain sulphur atom. Noticeably, the cycle.P folder are most dominant (Figure 3) except cycle.other folder, in particular when Uracil, Cytosine and Guanine-binding proteins are references. 


\section{Enumeration of Ribose Structural Isosteres}

Most of ligands are found to be anchored at the adenine-ribose sites, as can be inferred from the higher number of replacements of adenylic ribose (Figure 3A-C) compared to guanylic, cytidylic and thymidinic ones (Figure 3D-L). Among all possible LSR of ribose for different nucleotide except referencing with ADP and ATP, cyclic moieties containing phosphorus (designated as cycle.P folder, the grey pie in Figure 3A, D-L) remarkably outnumber other fragment replacements.

Classification of the structural replacements is important while complicated task. Except SMILES codes-based data sorting method described above, we furthermore tried to cluster the fragments according to the shape and electrostatic potential scores calculated by ShaEP, which are integrated into the computational workflow. For each cluster of fragments, neither electrostatic potential nor shape favour the classification of the fragments, implying the difficulty to address this task (Figure 4). We therefore maintain the SMILES based segregation, due to the advantage of helping the analysis and interpretation.

Apolar aliphatic ring. The data relative to the examples presented in this section, replacements of ribose is given in Table 2. The examples of SARs discussed are presented in Table 3.

Apolar aliphatic ring commonly appeared in drug development project[60], but hardly addressed as an isostere of ribose. Our survey disclosed several cases of its structural replacement as such. In bovine ribosomal S6 kinases RPS6KB1 (S6K1) (example 1, Figure 5A-C), ligand 15e in Table 3 offers the highest IC $\mathrm{C}_{50}$ of $0.0198 \mu \mathrm{M}$ among $\mathrm{N}-1$ substituted benzimidazole oxadiazole analogs[61]. The compound with ethyl replacement (15c in Table 3, IC $\mathrm{I}_{50}$ of $0.366 \mu \mathrm{M}$ ) presents 18 -fold lower $\mathrm{IC}_{50}$ toward $\mathrm{S} 6 \mathrm{~K} 1$, the compound $15 \mathrm{~d}$ with benzyl replacement completely loses activity, suggesting that a pocket small and confined exists, only cyclopropylmethyl group can tightly fits the hydrophobic pocket formed by Gly50, Tyr54, Val57, and Phe327 (Figure 5B). Besides, compounds containing this ring system had been also been reported as inhibitors of the AGC kinases mitogen and stress-activated protein kinase (MSK1)[62], Rho kinase, and ATPbinding site of protein kinase[63]. Although apolar aliphatic ring cannot mimic the hydrogen-bonding interactions of the ribose 2'- and 3'-hydroxyls toward biological target, it is often observed that they occupy space close to where the ribose ring of nucleoside binds, exemplified by KS4's[64] cyclobutyl moiety (Figure 5F) in c-Src kinase, cyclopentane group(Figure 5I) of ML8[65] in phosphatidylinositol 3-kinase and cyclohexylmethyl group of NW1 in cyclin-dependent kinase (Figure 5L)[66]. A closer look underline that the driven force anchoring cycloaliphatic ring in proximity to the ribose is hydrophobic interactions established by a hydrophobic patch on the glycine-rich loop of the receptor, assisted by the bulk of residues of valine for instance. The fused bicyclohexyl group of ligand BYB (VX-787N in reference[67]) packed with Phe325 residue of influenza B cap-binding domain[67], where ribose moiety of GTP occupied the space of biclohexyl (Figure 50).

\section{Table 2. Ribose Replacements That are Structural Replacement of Ribose: Examples 1-4}




\begin{tabular}{|c|c|c|c|c|c|c|c|}
\hline no. & figure & target protein & $\begin{array}{l}\text { target } \\
\text { PDB } \\
\text { code }\end{array}$ & $\begin{array}{l}\text { target } \\
\text { ligand }\end{array}$ & $\begin{array}{l}\text { reference } \\
\text { protein }\end{array}$ & $\begin{array}{l}\text { reference } \\
\text { ligand }\end{array}$ & $\begin{array}{l}\text { replacements and } \\
\text { comments }\end{array}$ \\
\hline 1 & $\begin{array}{l}\text { Figure } \\
5 A-C\end{array}$ & $\begin{array}{l}\text { Bos taurus } \\
\text { S6K1 }\end{array}$ & $4 \mathrm{C} 36$ & zo9 & 1Q24 & ATP & $\begin{array}{l}\text { cyclopropylmethyl, } \\
\text { mutated LSR } \\
\text { protein F54Y }\end{array}$ \\
\hline 2 & $\begin{array}{l}\text { Figure } \\
5 \mathrm{D}-\mathrm{F}\end{array}$ & $\begin{array}{l}\text { Homo sapiens c-Src } \\
\text { kinase }\end{array}$ & 3EN5 & KS4 & $3 D Q X$ & AMP & cyclobutyl \\
\hline 3 & $\begin{array}{l}\text { Figure } \\
5 \mathrm{G}-\mathrm{I}\end{array}$ & $\begin{array}{l}\text { Homo } \\
\text { sapiens phosphoinositide } \\
\text { 3-kinase }\end{array}$ & $3 M L 8$ & ML8 & $1 \mathrm{E} 8 \mathrm{X}$ & ATP & cyclopentyl \\
\hline 4 & $\begin{array}{l}\text { Figure } \\
5 \mathrm{G}-1\end{array}$ & Homo sapiens $\mathrm{CDK} 2$ & $1 \mathrm{E} 1 \mathrm{X}$ & NW1 & 1B38 & ATP & cyclohexyl \\
\hline 5 & $\begin{array}{l}\text { Figure } \\
5 \mathrm{M}-0\end{array}$ & Influenza B virus PB2 & 6EUX & BYB & $5 \mathrm{EFC}$ & GTP & bicyclohexyl \\
\hline
\end{tabular}

\section{Table 3. Specific Examples of SARs that Illustrate Ribose Replacements}

\begin{tabular}{|c|c|c|c|c|c|c|c|}
\hline $\begin{array}{l}\text { Example } 1 \\
\text { (Figure 4A- } \\
\text { C) } \\
\text { Compound } \\
5 \text { from } \\
\text { reference } \\
{[61]}\end{array}$ & 15e (zO9) & $15 a$ & $15 b$ & $15 c$ & $15 d$ & 10 & 11 \\
\hline $\begin{array}{l}\text { S6K1 } \\
\mathrm{IC}_{50}(\mu \mathrm{M})\end{array}$ & 0.0198 & $\begin{array}{l}0.194 \\
0.14[62]\end{array}$ & 0.598 & 0.366 & $>100$ & 0.34 & 6.98 \\
\hline PDB file & $4 \mathrm{C} 36$ & - & - & - & - & - & - \\
\hline
\end{tabular}

Polar aliphatic ring. The data relative to the examples presented in this section, replacements of ribose is specified in Table 4.

Table 4. Ribose Replacements That are Bioisostere of Ribose: Examples 5-6

\begin{tabular}{|clllllll|}
\hline no. & & & $\begin{array}{l}\text { target } \\
\text { PDB } \\
\text { code }\end{array}$ & $\begin{array}{l}\text { target } \\
\text { ligand }\end{array}$ & $\begin{array}{l}\text { reference } \\
\text { protein }\end{array}$ & $\begin{array}{l}\text { reference } \\
\text { ligand }\end{array}$ & $\begin{array}{l}\text { replacements and } \\
\text { comments }\end{array}$ \\
\hline 5 & $\begin{array}{l}\text { Figure } \\
6 \mathrm{~A}-\mathrm{C}\end{array}$ & $\begin{array}{l}\text { Homo } \\
\text { sapiens PDE4B }\end{array}$ & 3KKT & 0CP & 1TB5 & AMP & $\begin{array}{l}\text { (target protein } \\
\text { 2(1H)-one }\end{array}$ \\
\hline 6 & $\begin{array}{l}\text { Figure } \\
\text { 6D-F }\end{array}$ & $\begin{array}{l}\text { Homo sapiens C-Src } \\
\text { tyrosine kinase }\end{array}$ & 2BDF & 24A & 3DQX & AMP & 4-amino-cyclohexyl \\
\hline
\end{tabular}

Six-member heterocyclic ring can also be the structural replacement of ribose. In Homo sapiens PDE4B tetrahydropyrimidin-2 $(1 \mathrm{H})$-one is close to ribose ring of AMP, the carbonyl of OCP (Figure 6B) align with 3'- 
hydroxyl of AMP ribose; a water is conserved but shift a bit between structures complexes (Figure 6C) as such that bridge two histidine resides and ligands' oxygen atoms, implying 3'-hydroxyl of AMP is hydrogen bond acceptor. The 4-amino-cyclohexyl substituent at the C2 position of the purine ring in 24A is oriented toward the ribose-binding portion of the ATP site. Herein, the amino group of 24A is 2'-hydroxyl the counterpart of (Figure $6 \mathrm{E})$ in term of molecule recognition pattern as such a conserved water molecule bifurcately hydrogen bonded to the main NH of Ser345 and side chain of Asp348[68]. Besides, the amino of 24A makes extensive contacts with backbone $\mathrm{NH}$ of GIn275 through a bridge water molecule.

Aromatic ring. The data relative to the examples presented in this section, replacements of ribose is given in Table 5. The UMP binding pocket of influenza A virus endonuclease is open and large, therefor can accept molecules with different scaffold. For instance, T-shaped ligand 0 N8 access the pocket while has no fragment overlaid with U5P ribose[69]. Butterfly-like ligand E4Z co-crystalize to influenza A virus endonuclease, with one wing consisting of a metal chelating polar head-group and another wing, a lipophilic tail-group that makes van der Waals contacts with specific residues of the active site pocket. One of the tail-group aromatic ring of E4Z space the position of U5P ribose (Figure 7B), intramolecularly $\pi-\pi$ stacked with dihydropyridine (centroid distance of benzene $\cdots$ pyridine $3.8 \AA$ ); the binding of E4Z to influenza A virus endonuclease significantly stabilizes the structure, with more than $+32{ }^{\circ} \mathrm{C} \Delta \mathrm{T}_{\mathrm{m}}$ from $46^{\circ} \mathrm{C}$ to $78{ }^{\circ} \mathrm{C}[70]$. Similar to $\mathrm{E} 4 \mathrm{Z}$, by replacement of morpholine with trifluoropropane (Figure 7D) to obtain analogue compound R07[71] which has identical binding mode as such. The chloro-benzyl group of ligand BYE contact via hydrophobic interaction with PDE9's subpocket which made of residues His252, Met365, Leu420, Tyr424, and Phe456[72]; the subpocket is also occupied by ribose of 5GP who is endogenous ligand of PDEs[73]. Ligand BYE had an $\mathrm{IC}_{50}$ of $88 \mathrm{nM}$ for the wild type PDE9A, its enantiomer PDB is 4 times more potent (22 nM), attributed to different orientations of fluoromethyl groups of BYE and PDB[72].

Table 5. Ribose Replacements That are Bioisostere of Ribose: Examples 7-9

\begin{tabular}{|c|c|c|c|c|c|c|c|}
\hline no. & figure & target protein & $\begin{array}{l}\text { target } \\
\text { PDB } \\
\text { code }\end{array}$ & $\begin{array}{l}\text { target } \\
\text { ligand }\end{array}$ & $\begin{array}{l}\text { reference } \\
\text { protein }\end{array}$ & $\begin{array}{l}\text { reference } \\
\text { ligand }\end{array}$ & $\begin{array}{l}\text { replacements } \\
\text { and comments }\end{array}$ \\
\hline 7 & $\begin{array}{l}\text { Figure } \\
A-C\end{array}$ & $\begin{array}{l}\text { Influenza A virus } \\
\text { endonuclease }\end{array}$ & 6FS6 & E4Z & 5DEB & U5P & benzene \\
\hline 8 & $\begin{array}{l}\text { Figure } \\
A, D, E\end{array}$ & $\begin{array}{l}\text { Influenza A virus } \\
\text { endonuclease }\end{array}$ & 5VPT & R07 & 5DEB & U5P & benzene \\
\hline 9 & $\begin{array}{l}\text { Figure } \\
\text { F-H }\end{array}$ & $\begin{array}{l}\text { Homo sapiens } \\
\text { hydrolase }\end{array}$ & $3 \mathrm{~K} 3 \mathrm{H}$ & BYE & $3 D Y 8$ & $5 \mathrm{GP}$ & cholobenzene \\
\hline
\end{tabular}

Substituted aromatic ring. The data relative to the examples presented in this section, replacements of ribose is given in Table 6. The examples of SARs discussed are presented in Table 7.

\section{Table 6. Ribose Replacements That are Bioisostere of Ribose: Examples 7-8}




\begin{tabular}{|clllllll|}
\hline no. & figure & target protein & $\begin{array}{l}\text { target } \\
\text { PDB } \\
\text { code }\end{array}$ & $\begin{array}{l}\text { target } \\
\text { ligand }\end{array}$ & $\begin{array}{l}\text { reference } \\
\text { protein }\end{array}$ & $\begin{array}{l}\text { reference } \\
\text { ligand }\end{array}$ & $\begin{array}{l}\text { replacements } \\
\text { and comments }\end{array}$ \\
\hline 10 & $\begin{array}{l}\text { Figure } \\
8 \mathrm{~A}-\mathrm{C}\end{array}$ & $\begin{array}{l}\text { Homo sapiens } \\
\text { kinase Pim1 }\end{array}$ & 1YXX & LI7 & $1 \mathrm{YXU}$ & AMP & phenol \\
\hline 11 & $\begin{array}{l}\text { Figure } \\
8 \mathrm{~A}, \mathrm{E}, \mathrm{F}\end{array}$ & $\begin{array}{l}\text { Homo sapiens } \\
\text { kinase Pim1 }\end{array}$ & 4LMU & QUE & 1YXU & AMP & catechol \\
\hline
\end{tabular}

\section{Table 7. Specific Examples of SARs that Illustrate Ribose Replacements}

\begin{tabular}{|c|c|l|c|c|}
\hline $\begin{array}{l}\text { Example 11 (Figure 8 } \\
\text { A, E, F) Compound } \\
\text { from reference[74] }\end{array}$ & Quercetin (QUE) & $\begin{array}{l}\text { Quercetagetin } \\
\text { (MYU) }\end{array}$ & $\begin{array}{c}\text { Myricetin (MYC) } \\
\text { Pentahydroxyflavone } \\
\text { (MYF) }\end{array}$ \\
\hline${\text { Pim1 IC } \mathrm{C}_{50}(\mu \mathrm{M})}^{\mathrm{PDB} \text { file }}$ & 1.10 & 0.34 & 0.78 & 0.65 \\
\hline
\end{tabular}

In Pim1-AMP co-crystal structure, the ribose group is found deep inside the pocket and the 3'-OH joins an extensive hydrogen bond network formed inside the pocket by Lys67, Glu89, the backbone NH of Phe187, and a water molecule (Figure 8A). The phenol of LI7[76] sits inside the same pocket (Figure 8B), with its hydroxyl group participating the highly conserved water mediated hydrogen bond network near Lys67, Glu89 and Phe187 in a direction similar to the 3'-OH of AMP. The same pocket also accommodates the catechol of QUE, with its two hydroxyl groups being involved (Figure 8D) hydrogen bond network and the water molecule experiencing negligible shift comparing to reference[74]. Ligand QUE in Table X exhibit activity of $\mathrm{IC}_{50} 1.10 \mu \mathrm{M}$ (Table 1 in reference [77]) toward Pim1, the $\mathrm{OH}$ group addition at 6 position of QUE A ring give MYU with $\mathrm{IC}_{50}$ of $0.34 \mu \mathrm{M}$, the highest inhibitory among flavonoids analogs; the additional $\mathrm{OH}$ group at $5^{\prime}$ position of $\mathrm{B}$ ring result in MYC with the $\mathrm{IC}_{50}$ of $0.78 \mu \mathrm{M}$, a slight activity increase; the addition of $\mathrm{OH}$ group at 5 ' position of $\mathrm{B}$ ring and the deletion of $\mathrm{OH}$ group at 3 position of $\mathrm{C}$ ring assign MYF $\mathrm{IC}_{50}$ of $0.65 \mu \mathrm{M}$, nearly double the activity of QUE. Of these four compounds cocrystallized with Pim1, QUE and MYU orients the B ring (see reference[75]) inside the binding pocket whereas MYC and MYF flip the B ring out toward solvent.

Substituted heteroaromatic rings. The data relative to the examples presented in this section, replacements of ribose is given in Table 8. The examples of SARs discussed are presented in Table 9.

Table 8. Ribose Replacements That are Bioisostere of Ribose: Examples 12-14 


\begin{tabular}{|clllllll|}
\hline no. & figure & target protein & $\begin{array}{l}\text { target } \\
\text { PDB } \\
\text { code }\end{array}$ & $\begin{array}{l}\text { target } \\
\text { ligand }\end{array}$ & $\begin{array}{l}\text { reference } \\
\text { protein }\end{array}$ & $\begin{array}{l}\text { reference } \\
\text { ligand }\end{array}$ & $\begin{array}{l}\text { replacements and } \\
\text { comments }\end{array}$ \\
\hline 12 & $\begin{array}{l}\text { Figure } \\
8 \mathrm{~A}-\mathrm{C}\end{array}$ & $\begin{array}{l}\text { Homo sapiens } \\
\text { PDE4B }\end{array}$ & 1XM6 & $5 \mathrm{RM}$ & $1 \mathrm{ROR}$ & AMP & oxazolidin-2-one \\
\hline 13 & $\begin{array}{l}\text { Figure } \\
8 \mathrm{D}-\mathrm{F}\end{array}$ & $\begin{array}{l}\text { Homo sapiens } \\
\text { kinase Pim1 }\end{array}$ & $3 \mathrm{VC4}$ & 0FS & $1 \mathrm{YXU}$ & AMP & thiazolidinedione \\
\hline 14 & $\begin{array}{l}\text { Figure } \\
8 \mathrm{G}-\mathrm{I}\end{array}$ & $\begin{array}{l}\text { Homo sapiens } \\
\text { kinase Pim1 }\end{array}$ & 4KOY & 10A & 1YXU & AMP & pyrazolopyrimidone \\
\hline
\end{tabular}

\section{Table 9 Specific Examples of SARs that Illustrate Ribose Replacements}

\begin{tabular}{|l|l|c|c|c|c|}
\hline $\begin{array}{l}\text { Example 12 } \\
\text { (Figure 9 A- } \\
\text { C) } \\
\text { Compound } \\
\text { from } \\
\text { reference[7 } \\
8]\end{array}$ & $\begin{array}{l}\text { (R)-Mesopram } \\
\text { (5RM) }\end{array}$ & Filaminast (FIL) & Cilomilast (CIO) & Piclamilast (PIL) & (R)-Rolipram (ROL) \\
\hline $\begin{array}{l}\text { PDE4B IC50 } \\
(\mu \mathrm{M})\end{array}$ & 0.42 & 0.96 & 0.025 & 0.000041 & 0.57 \\
\hline PDB file & $1 \mathrm{XM6}$ & $1 \mathrm{XLZ}$ & $1 \mathrm{XLX}$ & $1 \mathrm{XM} 4$ & $1 \mathrm{XMY}$ \\
\hline
\end{tabular}

Among homo sapiens phosphodiesterases 4B (PDE4B) dialkoxyphenyl inhibitors, the oxazolidinones moiety of mesopram (5RM)[79] insect with AMP ribose and protrude into M pocket, with its carbonyl participating the hydrogen bond network involving the backbone carboxyl oxygen of Leu510, Cme430 and a conserved water (Figure 9B), similar interactions mode of AMP 2'-OH. (R)-Mesopram obtains $\mathrm{IC}_{50}$ of $0.42 \mu \mathrm{M}$ toward PDE4B, its analogue rolipram (ROL) with smaller pyrrolidinone substituent result in lower binding affinity of $\mathrm{IC}_{50} 0.57 \mu \mathrm{M}$, the hydroxamate substituents of filaminast (FIL) forms a similar number of interactions with residue in $\mathrm{M}$ pocket hence has similar binding affinity of $0.96 \mu \mathrm{M}$, the carboxycyclohexyl substituent of $\mathrm{ClO}$ forms with residues in the $\mathrm{M}$ pocket compared to the substituents in FIL and 5RM therefore is a more potent inhibitor with $\mathrm{IC}_{50}$ of $0.025 \mu \mathrm{M}$, about 17 -fold increase of binding affinity; impressively, extensive interactions formed between piclamilast (PIL) and active site residue make it the most potent molecules in this series of inhibitor with $\mathrm{IC}_{50}$ of $4.1 \times 10^{-2} \mathrm{nM}$ toward PDE4B. In homo sapiens kinase Pim1, the thiazolidinedione group of OFS intersects and is perpendicular with the ribose of AMP, with one of its carbonyl hydrogen bonding to Lys 67 , another carbonyl participating the hydrogen bond network containing the backbone $\mathrm{NH}$ of Phe 160, Glu 162 residue and a conservative water, similar to the role of AMP 3'-OH (Figure 9E). Noticeable, the continuous fragment-based optimization of OFS has led to the most potent compound (6 in reference[80]) with $\mathrm{IC}_{50}$ of $0.42 \mathrm{nM}$ toward Pim1. In Pim-1, the pyrazolopyrimidone core of 10A lays on the space AMP ribose, with hydroxyl group direct hydrogen bonding to Lys 67 residue, pyrazolopyrimidine interacting with Val 52 residue through hydrophobic interaction;[81] 3'-OH of AMP also makes the key hydrogen bond contact with Lys67 residue.

Heteroaromatic rings. The data relative to the examples presented in this section, replacements of ribose is given in Table 10. 


\begin{tabular}{|clllllll|}
\hline no. & figure & target protein & $\begin{array}{l}\text { target } \\
\text { PDB } \\
\text { code }\end{array}$ & $\begin{array}{l}\text { target } \\
\text { ligand }\end{array}$ & $\begin{array}{l}\text { reference } \\
\text { protein }\end{array}$ & $\begin{array}{l}\text { reference } \\
\text { ligand }\end{array}$ & $\begin{array}{l}\text { replacements and } \\
\text { comments }\end{array}$ \\
\hline 15 & $\begin{array}{l}\text { Figure } \\
9 \mathrm{~A}-\mathrm{C}\end{array}$ & $\begin{array}{l}\text { Homo sapiens } \\
\text { PDE4B }\end{array}$ & 3L54 & LXX & 1E8X & ATP & pyridine \\
\hline 16 & $\begin{array}{l}\text { Figure } \\
\text { 9D-F }\end{array}$ & $\begin{array}{l}\text { Homo sapiens } \\
\text { kinase Pim1 }\end{array}$ & 4LL5 & SK8 & 1YXU & AMP & imidazothiazole \\
\hline 17 & $\begin{array}{l}\text { Figure } \\
\text { 9D, G-H }\end{array}$ & $\begin{array}{l}\text { Homo sapiens } \\
\text { kinase Pim1 }\end{array}$ & 3BGQ & VX2 & 1YXU & AMP & triazolopyridazine \\
\hline
\end{tabular}

In PI3Ka, pyridine moiety of LXX interlock with ribose of ATP (Figure $10 \mathrm{C}$ ) with 2'-hydroxyl pass through the ring[82], and achieve $7 \mathrm{nM}$ of $\mathrm{IC}_{50}$. Structurally, ribose is regarded as the transition between purine/pyrimidine and phosphate, its structural replacement may also take the same role. Kinase inhibitor SK8 (SKF86002 in reference[74]) binds to the ATP binding sites of kinase Pim1, makes many hydrophobic interactions typical of other ATP mimetic inhibitors with imidazothiazole shouldering both pyridine and fluoro-substituted phenyl ring (Figure $10 \mathrm{E}$ ). SK8 does not form direct hydrogen-bonding interactions with protein, hence has no kinase inhibition detected even at $100 \mathrm{mM}$. However, triazolopyridazine replacement (Figure $\mathbf{9}$ G) of VX2 accept a hydrogen bond from the side chain of Lys67, giving rise to the inhibition constant $K_{\mathrm{i}}$ of $0.011 \mu \mathrm{M}[83]$, a dramatical increase.

Amide. The data relative to the examples presented in this section, replacements of ribose is given in Table 11. The examples of SARs discussed are presented in Table 12 .

Table 11 Ribose Replacements That are Bioisostere of Ribose: Examples 18-21

\begin{tabular}{|c|c|c|c|c|c|c|c|}
\hline no. & figure & target protein & $\begin{array}{l}\text { target } \\
\text { PDB } \\
\text { code }\end{array}$ & $\begin{array}{l}\text { target } \\
\text { ligand }\end{array}$ & $\begin{array}{l}\text { reference } \\
\text { protein }\end{array}$ & $\begin{array}{l}\text { reference } \\
\text { ligand }\end{array}$ & $\begin{array}{l}\text { replacements } \\
\text { and } \\
\text { comments }\end{array}$ \\
\hline 18 & $\begin{array}{l}\text { Figure } \\
11 A-C\end{array}$ & Homo sapiens Pim-1 kinase & 3VBV & OFK & $1 Y X U$ & AMP & carboxamide \\
\hline 19 & $\begin{array}{l}\text { Figure } \\
11 \mathrm{D}-\mathrm{F}\end{array}$ & $\begin{array}{l}\text { Homo sapiens death } \\
\text { associated protein kinase } 3\end{array}$ & 3BHY & 7CP & $2 \mathrm{~W} 4 \mathrm{~J}$ & ADP & y-lactam \\
\hline 20 & $\begin{array}{l}\text { Figure } \\
11 \mathrm{G}-\mathrm{I}\end{array}$ & $\begin{array}{l}\text { Homo sapiens } \\
\text { cyclic GMP-AMP synthase }\end{array}$ & $6 \mathrm{MJW}$ & JUJ & 4JLZ & UTP & cycle-amide \\
\hline 21 & $\begin{array}{l}\text { Figure } \\
11 \mathrm{~J}-\mathrm{L}\end{array}$ & $\begin{array}{l}\text { Pseudomonas aeruginosa } \\
\text { PAO1 }\end{array}$ & 4B42 & 942 & $4 \mathrm{HO} 9$ & UTP & benzamide \\
\hline
\end{tabular}

Table 12 Specific Examples of SARs that Illustrate Ribose Replacements 


\begin{tabular}{|c|c|c|c|c|}
\hline $\begin{array}{lr}\text { Example } & 21 \\
\text { (Figure } 11 & \mathrm{~J}-\mathrm{L} \text { ) } \\
\text { Compound from } \\
\text { reference[84] }\end{array}$ & 1 (HNR) & $3(942)$ & 4 (NIQ) & 5 \\
\hline$I C_{50}(\mu \mathrm{M})$ & $0.21 \pm 0.03$ & n.d. & n.d. & $5.9 \pm 2.9$ \\
\hline $\begin{array}{c}\% \text { inhibition at } \\
10 \mu \mathrm{M}\end{array}$ & 100 & $30.3 \pm 4.1$ & $30.0 \pm 2.0$ & $71.1 \pm 1.2$ \\
\hline $\begin{array}{c}\% \text { inhibition at } \\
60 \mu \mathrm{M}\end{array}$ & 100 & $75.7 \pm 3.9$ & $39.4 \pm 4.6$ & 100 \\
\hline PDB file & 4ARW & 4B42 & $4 \mathrm{~B} 2 \mathrm{X}$ & - \\
\hline
\end{tabular}

The carboxyl oxygen of OFK accept a hydrogen bond from the Lys67 residue directly, while NH of OFK, backbone $\mathrm{NH}$ of Phe160 and residue of Glu62 form hydrogen bond forms hydrogen bond network[80] in AMP binding site of Pim-1 (Figure 11 B); together the terminal amide of OFK is bifurcatedly replaced by 3'-OH of AMP (Figure 11 A). In the DAPK3 complex, 7CP's s y-lactam carbonyl establishes a hydrogen bond with a water molecule (Figure $11 \mathrm{E}$ ) in the active site which itself is involved in a hydrogen bond network with Ser21 backbone carbonyl[85], in which AMP ribose and pyridone ring interweaved. Ligand JUJ (G150 in reference[86]) localized within the GTP binding pocket of cyclic GMP-AMP synthase (Figure $11 \mathrm{H}$ ), with the part of the hydroxyl-ethanone side chain attached to the non-planar six-membered ring sharing the same space with UTP ribose moiety ((Figure $11 \mathrm{I})$, hydrogen-bonded with Ser434 (Figure $11 \mathrm{H}$ ). Pseudomonas aeruginosa RmIA was screened against a library and identified HNR (compound 1 in Table 12) give $I_{50}$ values of $0.22 \mu \mathrm{M}, 100 \%$ inhibition at $10 \mu \mathrm{M}$, both 942 and NIQ (compound 3, 4 in Table 12 conrrespondingly) show about 30\% inhibition at $10 \mu \mathrm{M}$, while 942 is $36 \%$ more potent than NIQ at $60 \mu \mathrm{M}$ concentration[84]. Ligand 942 is commercially available analogue of HNR while less potent, indicated that replacement of the sulfonamide in HNR by an amide in 942 or an alkyl substituent in NIQ was unfavorable. Herein, the carboxyl oxgen of amide in 942 hydrgen bonded to backbone (Figure $11 \mathrm{~K}$ ) NH of Gly115 that formed equivalent interction with 3'-OH of UTP (Figure $11 \mathrm{~L}$ ).

Sulfonamide. The data relative to the examples presented in this section, replacements of ribose is given in Table 13.

\section{Table 13 Ribose Replacements That are Bioisostere of Ribose: Examples 17-18}

\begin{tabular}{|ccllllll|}
\hline no. & & & $\begin{array}{l}\text { target } \\
\text { PDB } \\
\text { figure }\end{array}$ & $\begin{array}{l}\text { target } \\
\text { ligand } \\
\text { code }\end{array}$ & $\begin{array}{l}\text { reference } \\
\text { protein }\end{array}$ & $\begin{array}{l}\text { reference } \\
\text { ligand }\end{array}$ & $\begin{array}{l}\text { replacements } \\
\text { and comments }\end{array}$ \\
\hline 22 & $\begin{array}{l}\text { Figure } \\
11 \mathrm{~A}-\mathrm{C}\end{array}$ & $\begin{array}{l}\text { Homo sapiens } \\
\text { CDK }\end{array}$ & 2VTH & LZ2 & $4 I 3 Z$ & ADP & $\begin{array}{l}\text { sulfonamide } \\
\text { (Terminal) }\end{array}$ \\
\hline 23 & $\begin{array}{l}\text { Figure } \\
\text { 11D-F }\end{array}$ & $\begin{array}{l}\text { Homo sapiens } \\
\text { kinase Pim1 }\end{array}$ & 1YDS & IQS & 2W4J & ADP & $\begin{array}{l}\text { 2Wulfonamide } \\
\text { (Linker) }\end{array}$ \\
\hline
\end{tabular}

The sulfonamide moiety of LZ2 forms water mediated hydrogen bond to the backbone carbonyl of GIn131 and to the residue of Asp86 (Figure 12 B), partly occupy the ribose pocket[87], give $I_{50}$ of $120 \mu \mathrm{M}$ toward CDK2. Isoquinolinesulfonamide protein kinase inhibitor IQS acts in competition to ATP toward cAPK, give IC 50 of 1.2 
$\mu \mathrm{M}$. It shows the superposition with ATP (Figure $12 \mathrm{~F}$ ), One of the $\mathrm{SO}_{2}$ oxygens (0-2) of the sulfonamide superimposes roughly with the 0-4' ring oxygen, 0-1 is close to the amide of Gly-50, oriented for a weak interaction, a water molecule bridges one IQS sulfonyl oxygen to the carboxylate residue of Asp184. Another water molecule makes bidentate contacts with Glu127 residue carboxylate and backbone carboxyl of Leu49[88].

\section{Conclusion}

The robustness of our previously developed workflow is demonstrated by designating glycosyl ribose fragment of ligands as query moiety. By superimposing X-ray structures of homologous proteins, we have extracted 41652 structural isosteres, which partially reflected the chemical features of ribose and therefore can be considered as a rational structural replacement. Among them, we discussed 23 typical examples, categorized as apolar/polar aliphatic ring, substituted aromatic/heteroaromatic ring, amide and sulfoamide surrogate. In particular, the SAR analysis of a few cases are enumerated, with attempt to correlate these replacements/deviations with biological activities since structural optimization remains the fundamental mission of medicinal chemistry. During the (bio)isosteres identification process using this protocol, it is realized the water in ligand binding site is an important mediator to drive isosteres interchange but poorly understood, which might be worthy of investigation in future. Of course, it would be more eye-catching to generalize the workflow into user-friendly open-source browser application for any chemical fragments of interests.

\section{Declarations}

\section{Authors' contributions}

YZZ conceived and coordinated the study, drafted the manuscript. TL updated the workflows and performed the data analysis. ML curated the data and selected the examples illustrated. YL suggested the outline of the paper. All authors read and approved the final version of the paper.

\section{Funding}

This research was supported by Natural Science Basic Research Program of Shaanxi (Program No. 2020JM141), funded by Ningbo Natural Science Foundation (No. 202003N4006), sponsored by the Joint Research Funds of Department of Science \& Technology of Shaanxi Province, Northwestern Polytechnical University (No. 2020GXLH-Z-017).

\section{Availability of data and materials}

Scripts enabling reproduction of all the results obtained in the study are available at https://github.com/Yuezhou-Project/Isoldentifier.

\section{Competing interests}

The authors declare that they have no competing interests.

\section{References}


[1] R.A. Ward, S. Fawell, N. Floc'h, V. Flemington, D. McKerrecher, P.D. Smith, Challenges and Opportunities in Cancer Drug Resistance, Chem Rev, 121 (2021) 3297-3351.

[2] M. Rafehi, A. Neumann, Y. Baqi, E.M. Malik, M. Wiese, V. Namasivayam, C.E. Müller, Molecular Recognition of Agonists and Antagonists by the Nucleotide-Activated G Protein-Coupled P2Y2 Receptor, J Med Chem, 60 (2017) 8425-8440.

[3] E. Gregori-Puigjané, V. Setola, J. Hert, B.A. Crews, J.J. Irwin, E. Lounkine, L. Marnett, B.L. Roth, B.K. Shoichet, Identifying mechanism-of-action targets for drugs and probes, Proc Natl Acad Sci U S A, 109 (2012) 1117811183.

[4] D. Mendez, A. Gaulton, A.P. Bento, J. Chambers, M. De Veij, E. Félix, María P. Magariños, Juan F. Mosquera, P. Mutowo, M. Nowotka, M. Gordillo-Marañón, F. Hunter, L. Junco, G. Mugumbate, M. Rodriguez-Lopez, F. Atkinson, N. Bosc, Chris J. Radoux, A. Segura-Cabrera, A. Hersey, Andrew R. Leach, ChEMBL: towards direct deposition of bioassay data, Nucleic Acids Res, 47 (2019) D930-D940.

[5] M. Wirth, V. Zoete, O. Michielin, W.H. Sauer, SwissBioisostere: a database of molecular replacements for ligand design, Nucleic Acids Res, 41 (2013) D1137-1143.

[6] M. Tuyishime, R. Lawrence, S. Cocklin, Core chemotype diversification in the HIV-1 entry inhibitor class using field-based bioisosteric replacement, Bioorg Med Chem Lett, 26 (2016) 228-234.

[7] P. Ertl, Identification of Bioisosteric Substituents by a Deep Neural Network, J Chem Inf Model, 60 (2020) 3369-3375.

[8] C.R. Groom, I.J. Bruno, M.P. Lightfoot, S.C. Ward, The Cambridge Structural Database, Acta Crystallogr B Struct Sci Cryst Eng Mater, 72 (2016) 171-179.

[9] J.C. Cole, O. Korb, P. McCabe, M.G. Read, R. Taylor, Knowledge-Based Conformer Generation Using the Cambridge Structural Database, J Chem Inf Model, 58 (2018) 615-629.

[10] H.M. Berman, J. Westbrook, Z. Feng, G. Gilliland, T.N. Bhat, H. Weissig, I.N. Shindyalov, P.E. Bourne, The Protein Data Bank, Nucleic Acids Res, 28 (2000) 235-242.

[11] F.M.I. Hunter, A.P. Bento, N. Bosc, A. Gaulton, A. Hersey, A.R. Leach, Drug Safety Data Curation and Modeling in ChEMBL: Boxed Warnings and Withdrawn Drugs, Chem Res Toxicol, 34 (2021) 385-395.

[12] F.H. Allen, C.R. Groom, J.W. Liebeschuetz, D.A. Bardwell, T.S. Olsson, P.A. Wood, The hydrogen bond environments of $1 \mathrm{H}$-tetrazole and tetrazolate rings: the structural basis for tetrazole-carboxylic acid bioisosterism, J Chem Inf Model, 52 (2012) 857-866.

[13] E.A. Kennewell, P. Willett, P. Ducrot, C. Luttmann, Identification of target-specific bioisosteric fragments from ligand-protein crystallographic data, J Comput Aided Mol Des, 20 (2006) 385-394.

[14] M.P. Seddon, D.A. Cosgrove, V.J. Gillet, Bioisosteric Replacements Extracted from High-Quality Structures in the Protein Databank, ChemMedChem, 13 (2018) 607-613. 
[15] D.J. Wood, J. de Vlieg, M. Wagener, T. Ritschel, Pharmacophore fingerprint-based approach to binding site subpocket similarity and its application to bioisostere replacement, J Chem Inf Model, 52 (2012) 2031-2043.

[16] R. Khashan, FragVLib a free database mining software for generating "Fragment-based Virtual Library" using pocket similarity search of ligand-receptor complexes, J Cheminform, 4 (2012) 18.

[17] J. Desaphy, D. Rognan, sc-PDB-Frag: a database of protein-ligand interaction patterns for Bioisosteric replacements, J Chem Inf Model, 54 (2014) 1908-1918.

[18] S. Lešnik, B. Škrlj, N. Eržen, U. Bren, S. Gobec, J. Konc, D. Janežič, BoBER: web interface to the base of bioisosterically exchangeable replacements, J Cheminform, 9 (2017) 62.

[19] J. Konc, D. Janežič, ProBiS-ligands: a web server for prediction of ligands by examination of protein binding sites, Nucleic Acids Res, 42 (2014) W215-220.

[20] J. Shan, X. Pan, X. Wang, X. Xiao, C. Ji, FragRep: A Web Server for Structure-Based Drug Design by Fragment Replacement, J Chem Inf Model, 60 (2020) 5900-5906.

[21] A. Del-Corso, M. Cappiello, R. Moschini, F. Balestri, U. Mura, P.L. Ipata, The furanosidic scaffold of d-ribose: a milestone for cell life, Biochem Soc Trans, 47 (2019) 1931-1940.

[22] C.A. Abbas, A.A. Sibirny, Genetic control of biosynthesis and transport of riboflavin and flavin nucleotides and construction of robust biotechnological producers, Microbiol Mol Biol Rev, 75 (2011) 321-360.

[23] J. Xu, N.J. Green, C. Gibard, R. Krishnamurthy, J.D. Sutherland, Prebiotic phosphorylation of 2-thiouridine provides either nucleotides or DNA building blocks via photoreduction, Nat Chem, 11 (2019) 457-462.

[24] A.J. Gustafsson, L. Muraro, C. Dahlberg, M. Migaud, O. Chevallier, H.N. Khanh, K. Krishnan, N. Li, M.S. Islam, ADP ribose is an endogenous ligand for the purinergic P2Y1 receptor, Mol Cell Endocrinol, 333 (2011) 8-19.

[25] C. Huang, J. Hu, K.P. Subedi, A.H. Lin, O. Paudel, P. Ran, J.S. Sham, Extracellular Adenosine Diphosphate Ribose Mobilizes Intracellular $\mathrm{Ca}^{2+}$ via Purinergic-Dependent Ca2+ Pathways in Rat Pulmonary Artery Smooth Muscle Cells, Cell Physiol Biochem, 37 (2015) 2043-2059.

[26] H.C. Lee, Cyclic ADP-ribose and NAADP: fraternal twin messengers for calcium signaling, Sci China Life Sci, 54 (2011) 699-711.

[27] Y. Sun, Y. Ke, C. Li, J. Wang, L. Tu, L. Hu, Y. Jin, H. Chen, J. Gong, Z. Yu, Bifunctional and Unusual Amino Acid $\beta$ - or $\gamma$-Ester Prodrugs of Nucleoside Analogues for Improved Affinity to $\mathrm{ATB}^{0,+}$ and Enhanced Metabolic Stability: An Application to Floxuridine, J Med Chem, 63 (2020) 10816-10828.

[28] A.M. Liao, B. Cai, J.H. Huang, M. Hui, K.K. Lee, K.Y. Lee, C. Chun, Synthesis, anticancer activity and potential application of diosgenin modified cancer chemotherapeutic agent cytarabine, Food Chem Toxicol, 148 (2021) 111920.

[29] S. Holzer, N.J. Rzechorzek, I.R. Short, M. Jenkyn-Bedford, L. Pellegrini, M.L. Kilkenny, Structural Basis for Inhibition of Human Primase by Arabinofuranosyl Nucleoside Analogues Fludarabine and Vidarabine, ACS 
Chem Biol, 14 (2019) 1904-1912.

[30] Y. Hu, Y. Liu, A. Coates, Azidothymidine Produces Synergistic Activity in Combination with Colistin against Antibiotic-Resistant Enterobacteriaceae, Antimicrob Agents Chemother, 63 (2019).

[31] S.R. Miller, R.K. Hau, J.L. Jilek, M.N. Morales, S.H. Wright, N.J. Cherrington, Nucleoside Reverse Transcriptase Inhibitor Interaction with Human Equilibrative Nucleoside Transporters 1 and 2, Drug Metab Dispos, 48 (2020) 603-612.

[32] C.K.J. Young, J.H. Wheeler, M.M. Rahman, M.J. Young, The antiretroviral 2',3'-dideoxycytidine causes mitochondrial dysfunction in proliferating and differentiated HepaRG human cell cultures, J Biol Chem, 296 (2021) 100206.

[33] S. Kandil, C. Pannecouque, F.M. Chapman, A.D. Westwell, C. McGuigan, Polyfluoroaromatic stavudine (d4T) ProTides exhibit enhanced anti-HIV activity, Bioorg Med Chem Lett, 29 (2019) 126721.

[34] R.V. Somu, D.J. Wilson, E.M. Bennett, H.I. Boshoff, L. Celia, B.J. Beck, C.E. Barry, 3rd, C.C. Aldrich, Antitubercular nucleosides that inhibit siderophore biosynthesis: SAR of the glycosyl domain, J Med Chem, 49 (2006) 7623-7635.

[35] B. Zhang, G.K. Wagner, K. Weber, C. Garnham, A.J. Morgan, A. Galione, A.H. Guse, B.V. Potter, 2'-deoxy cyclic adenosine 5'-diphosphate ribose derivatives: importance of the 2'-hydroxyl motif for the antagonistic activity of 8-substituted cADPR derivatives, J Med Chem, 51 (2008) 1623-1636.

[36] A.H. Guse, Second messenger function and the structure-activity relationship of cyclic adenosine diphosphoribose (cADPR), Febs j, 272 (2005) 4590-4597.

[37] V.C. Bailey, S.M. Fortt, R.J. Summerhill, A. Galione, B.V. Potter, Cyclic aristeromycin diphosphate ribose: a potent and poorly hydrolysable $\mathrm{Ca}(2+)$-mobilising mimic of cyclic adenosine diphosphate ribose, FEBS Lett, 379 (1996) 227-230.

[38] K.P. Currie, K. Swann, A. Galione, R.H. Scott, Activation of $\mathrm{Ca}^{2+}$-dependent currents in cultured rat dorsal root ganglion neurones by a sperm factor and cyclic ADP-ribose, Mol Biol Cell, 3 (1992) 1415-1425.

[39] J.M. Swarbrick, R. Graeff, H. Zhang, M.P. Thomas, Q. Hao, B.V. Potter, Cyclic adenosine 5'-diphosphate ribose analogs without a "southern" ribose inhibit ADP-ribosyl cyclase-hydrolase CD38, J Med Chem, 57 (2014) 8517-8529.

[40] J. Xu, Z. Yang, W. Dammermann, L. Zhang, A.H. Guse, L.H. Zhang, Synthesis and agonist activity of cyclic ADP-ribose analogues with substitution of the northern ribose by ether or alkane chains, J Med Chem, 49 (2006) 5501-5512.

[41] A.H. Guse, Cyclic ADP-ribose (cADPR) and nicotinic acid adenine dinucleotide phosphate (NAADP): novel regulators of $\mathrm{Ca}^{2+}$-signaling and cell function, Curr Mol Med, 2 (2002) 273-282.

[42] C. Cakir-Kiefer, H. Muller-Steffner, N. Oppenheimer, F. Schuber, Kinetic competence of the cADP-ribose-CD38 complex as an intermediate in the CD38/NAD+ glycohydrolase-catalysed reactions: implication for CD38 
signalling, Biochem J, 358 (2001) 399-406.

[43] T. Tsuzuki, N. Sakaguchi, T. Kudoh, S. Takano, M. Uehara, T. Murayama, T. Sakurai, M. Hashii, H. Higashida, K. Weber, A.H. Guse, T. Kameda, T. Hirokawa, Y. Kumaki, B.V. Potter, H. Fukuda, M. Arisawa, S. Shuto, Design and synthesis of cyclic ADP-4-thioribose as a stable equivalent of cyclic ADP-ribose, a calcium ion-mobilizing second messenger, Angew Chem Int Ed Engl, 52 (2013) 6633-6637.

[44] R.A. Tromp, S. van Ameijde, C. Pütz, C. Sundermann, B. Sundermann, J.K. von Frijtag Drabbe Künzel, I.J. AP, Inhibition of nucleoside transport by new analogues of 4-nitrobenzylthioinosine: replacement of the ribose moiety by substituted benzyl groups, J Med Chem, 47 (2004) 5441-5450.

[45] Q. Dang, S.R. Kasibhatla, K.R. Reddy, T. Jiang, M.R. Reddy, S.C. Potter, J.M. Fujitaki, P.D. van Poelje, J. Huang, W.N. Lipscomb, M.D. Erion, Discovery of potent and specific fructose-1,6-bisphosphatase inhibitors and a series of orally-bioavailable phosphoramidase-sensitive prodrugs for the treatment of type 2 diabetes, J Am Chem Soc, 129 (2007) 15491-15502.

[46] M.R. Reddy, M.D. Erion, Relative binding affinities of fructose-1,6-bisphosphatase inhibitors calculated using a quantum mechanics-based free energy perturbation method, J Am Chem Soc, 129 (2007) 9296-9297.

[47] M.D. Erion, Q. Dang, M.R. Reddy, S.R. Kasibhatla, J. Huang, W.N. Lipscomb, P.D. van Poelje, Structure-guided design of AMP mimics that inhibit fructose-1,6-bisphosphatase with high affinity and specificity, J Am Chem Soc, 129 (2007) 15480-15490.

[48] C. Moreau, T. Kirchberger, J.M. Swarbrick, S.J. Bartlett, R. Fliegert, T. Yorgan, A. Bauche, A. Harneit, A.H. Guse, B.V. Potter, Structure-activity relationship of adenosine 5'-diphosphoribose at the transient receptor potential melastatin 2 (TRPM2) channel: rational design of antagonists, J Med Chem, 56 (2013) 10079-10102.

[49] B. Du, C.M. Chan, P.Y. Lee, L.H. Cheung, X. Xu, Z. Lin, W.Y. Yu, 2,2-difluorovinyl benzoates for diverse synthesis of gem-difluoroenol ethers by Ni-catalyzed cross-coupling reactions, Nat Commun, 12 (2021) 412.

[50] M.S. Malik, S.A. Ahmed, Althagafi, II, M.A. Ansari, A. Kamal, Application of triazoles as bioisosteres and linkers in the development of microtubule targeting agents, RSC Med Chem, 11 (2020) 327-348.

[51] P. Ertl, Craig plot 2.0: an interactive navigation in the substituent bioisosteric space, J Cheminform, 12 (2020) 8 .

[52] Y. Zhang, A. Borrel, L. Ghemtio, L. Regad, G. Boije Af Gennäs, A.C. Camproux, J. Yli-Kauhaluoma, H. Xhaard, Structural Isosteres of Phosphate Groups in the Protein Data Bank, J Chem Inf Model, 57 (2017) 499-516.

[53] T.S. Elliott, A. Slowey, Y. Ye, S.J. Conway, The use of phosphate bioisosteres in medicinal chemistry and chemical biology, MedChemComm, 3 (2012) 735-751.

[54] J. Shan, C. Ji, MolOpt: A Web Server for Drug Design using Bioisosteric Transformation, Curr Comput Aided Drug Des, 16 (2020) 460-466.

[55] A. Borrel, A.C. Camproux, H. Xhaard, Characterization of Ionizable Groups' Environments in Proteins and Protein-Ligand Complexes through a Statistical Analysis of the Protein Data Bank, ACS Omega, 2 (2017) 7359- 
[56] Y. Xu, S. Wang, Q. Hu, S. Gao, X. Ma, W. Zhang, Y. Shen, F. Chen, L. Lai, J. Pei, CavityPlus: a web server for protein cavity detection with pharmacophore modelling, allosteric site identification and covalent ligand binding ability prediction, Nucleic Acids Research, 46 (2018) W374-W379.

[57] N.G. Johansson, A. Turku, K. Vidilaseris, L. Dreano, A. Khattab, D. Ayuso Pérez, A. Wilkinson, Y. Zhang, M. Tamminen, E. Grazhdankin, A. Kiriazis, C.W.G. Fishwick, S. Meri, J. Yli-Kauhaluoma, A. Goldman, G. Boije Af Gennäs, H. Xhaard, Discovery of Membrane-Bound Pyrophosphatase Inhibitors Derived from an Isoxazole Fragment, ACS Med Chem Lett, 11 (2020) 605-610.

[58] W. L. \& DeLano, PyMOL, in, Schrödinger, 2020.

[59] R.A. Laskowski, M.B. Swindells, LigPlot+: multiple ligand-protein interaction diagrams for drug discovery, J Chem Inf Model, 51 (2011) 2778-2786.

[60] C. De Monte, S. Carradori, B. Bizzarri, A. Bolasco, F. Caprara, A. Mollica, D. Rivanera, E. Mari, A. Zicari, A. Akdemir, D. Secci, Anti-Candida activity and cytotoxicity of a large library of new N-substituted-1,3-thiazolidin-4one derivatives, Eur J Med Chem, 107 (2016) 82-96.

[61] S. Couty, I.M. Westwood, A. Kalusa, C. Cano, J. Travers, K. Boxall, C.L. Chow, S. Burns, J. Schmitt, L. Pickard, C. Barillari, P.C. McAndrew, P.A. Clarke, S. Linardopoulos, R.J. Griffin, G.W. Aherne, F.I. Raynaud, P. Workman, K. Jones, R.L. van Montfort, The discovery of potent ribosomal S6 kinase inhibitors by high-throughput screening and structure-guided drug design, Oncotarget, 4 (2013) 1647-1661.

[62] M.J. Bamford, M.J. Alberti, N. Bailey, S. Davies, D.K. Dean, A. Gaiba, S. Garland, J.D. Harling, D.K. Jung, T.A. Panchal, C.A. Parr, J.G. Steadman, A.K. Takle, J.T. Townsend, D.M. Wilson, J. Witherington, (1H-imidazo[4,5c]pyridin-2-yl)-1,2,5-oxadiazol-3-ylamine derivatives: a novel class of potent MSK-1-inhibitors, Bioorg Med Chem Lett, 15 (2005) 3402-3406.

[63] U. Bandarage, B. Hare, J. Parsons, L. Pham, C. Marhefka, G. Bemis, Q. Tang, C.S. Moody, S. Rodems, S. Shah, C. Adams, J. Bravo, E. Charonnet, V. Savic, J.H. Come, J. Green, 4-(Benzimidazol-2-yl)-1,2,5-oxadiazol-3ylamine derivatives: potent and selective p70S6 kinase inhibitors, Bioorg Med Chem Lett, 19 (2009) 5191-5194.

[64] B. Apsel, J.A. Blair, B. Gonzalez, T.M. Nazif, M.E. Feldman, B. Aizenstein, R. Hoffman, R.L. Williams, K.M. Shokat, Z.A. Knight, Targeted polypharmacology: discovery of dual inhibitors of tyrosine and phosphoinositide kinases, Nat Chem Biol, 4 (2008) 691-699.

[65] H. Cheng, C. Li, S. Bailey, S.M. Baxi, L. Goulet, L. Guo, J. Hoffman, Y. Jiang, T.O. Johnson, T.W. Johnson, D.R. Knighton, J. Li, K.K. Liu, Z. Liu, M.A. Marx, M. Walls, P.A. Wells, M.J. Yin, J. Zhu, M. Zientek, Discovery of the Highly Potent PI3K/mTOR Dual Inhibitor PF-04979064 through Structure-Based Drug Design, ACS Med Chem Lett, 4 (2013) 91-97.

[66] C.E. Arris, F.T. Boyle, A.H. Calvert, N.J. Curtin, J.A. Endicott, E.F. Garman, A.E. Gibson, B.T. Golding, S. Grant, R.J. Griffin, P. Jewsbury, L.N. Johnson, A.M. Lawrie, D.R. Newell, M.E. Noble, E.A. Sausville, R. Schultz, W. Yu, 
Identification of novel purine and pyrimidine cyclin-dependent kinase inhibitors with distinct molecular interactions and tumor cell growth inhibition profiles, J Med Chem, 43 (2000) 2797-2804.

[67] A. Pflug, S. Gaudon, P. Resa-Infante, M. Lethier, S. Reich, W.M. Schulze, S. Cusack, Capped RNA primer binding to influenza polymerase and implications for the mechanism of cap-binding inhibitors, Nucleic Acids Research, 46 (2017) 956-971.

[68] D. Dalgarno, T. Stehle, S. Narula, P. Schelling, M.R. van Schravendijk, S. Adams, L. Andrade, J. Keats, M. Ram, L. Jin, T. Grossman, I. MacNeil, C. Metcalf, 3rd, W. Shakespeare, Y. Wang, T. Keenan, R. Sundaramoorthi, R. Bohacek, M. Weigele, T. Sawyer, Structural basis of Src tyrosine kinase inhibition with a new class of potent and selective trisubstituted purine-based compounds, Chem Biol Drug Des, 67 (2006) 46-57.

[69] M.-S. Song, G. Kumar, W.R. Shadrick, W. Zhou, T. Jeevan, Z. Li, P.J. Slavish, T.P. Fabrizio, S.-W. Yoon, T.R. Webb, R.J. Webby, S.W. White, Identification and characterization of influenza variants resistant to a viral endonuclease inhibitor, Proceedings of the National Academy of Sciences, 113 (2016) 3669.

[70] S. Omoto, V. Speranzini, T. Hashimoto, T. Noshi, H. Yamaguchi, M. Kawai, K. Kawaguchi, T. Uehara, T. Shishido, A. Naito, S. Cusack, Characterization of influenza virus variants induced by treatment with the endonuclease inhibitor baloxavir marboxil, Sci Rep, 8 (2018) 9633.

[71] J.C. Jones, G. Kumar, S. Barman, I. Najera, S.W. White, R.J. Webby, E.A. Govorkova, Identification of the I38T PA Substitution as a Resistance Marker for Next-Generation Influenza Virus Endonuclease Inhibitors, mBio, 9 (2018).

[72] H. Wang, X. Luo, M. Ye, J. Hou, H. Robinson, H. Ke, Insight into Binding of Phosphodiesterase-9A Selective Inhibitors by Crystal Structures and Mutagenesis, Journal of Medicinal Chemistry, 53 (2010) 1726-1731.

[73] S. Liu, M.N. Mansour, K.S. Dillman, J.R. Perez, D.E. Danley, P.A. Aeed, S.P. Simons, P.K. LeMotte, F.S. Menniti, Structural basis for the catalytic mechanism of human phosphodiesterase 9, Proceedings of the National Academy of Sciences, 105 (2008) 13309-13314.

[74] L.J. Parker, S. Taruya, K. Tsuganezawa, N. Ogawa, J. Mikuni, K. Honda, Y. Tomabechi, N. Handa, M. Shirouzu, S. Yokoyama, A. Tanaka, Kinase crystal identification and ATP-competitive inhibitor screening using the fluorescent ligand SKF86002, Acta Crystallogr D Biol Crystallogr, 70 (2014) 392-404.

[75] S. Holder, M. Zemskova, C. Zhang, M. Tabrizizad, R. Bremer, J.W. Neidigh, M.B. Lilly, Characterization of a potent and selective small-molecule inhibitor of the PIM1 kinase, Mol Cancer Ther, 6 (2007) 163-172.

[76] A. Kumar, V. Mandiyan, Y. Suzuki, C. Zhang, J. Rice, J. Tsai, D.R. Artis, P. Ibrahim, R. Bremer, Crystal structures of proto-oncogene kinase Pim1: a target of aberrant somatic hypermutations in diffuse large cell lymphoma, J Mol Biol, 348 (2005) 183-193.

[77] S. Holder, M. Zemskova, C. Zhang, M. Tabrizizad, R. Bremer, J.W. Neidigh, M.B. Lilly, Characterization of a potent and selective small-molecule inhibitor of the PIM1 kinase, Mol. Cancer Ther., 6 (2007) 163-172. 
[78] G.L. Card, B.P. England, Y. Suzuki, D. Fong, B. Powell, B. Lee, C. Luu, M. Tabrizizad, S. Gillette, P.N. Ibrahim, D.R. Artis, G. Bollag, M.V. Milburn, S.H. Kim, J. Schlessinger, K.Y. Zhang, Structural basis for the activity of drugs that inhibit phosphodiesterases, Structure, 12 (2004) 2233-2247.

[79] G.L. Card, B.P. England, Y. Suzuki, D. Fong, B. Powell, B. Lee, C. Luu, M. Tabrizizad, S. Gillette, P.N. Ibrahim, D.R. Artis, G. Bollag, M.V. Milburn, S.-H. Kim, J. Schlessinger, K.Y.J. Zhang, Structural Basis for the Activity of Drugs that Inhibit Phosphodiesterases, Structure, 12 (2004) 2233-2247.

[80] A.C. Good, J. Liu, B. Hirth, G. Asmussen, Y. Xiang, H.P. Biemann, K.A. Bishop, T. Fremgen, M. Fitzgerald, T. Gladysheva, A. Jain, K. Jancsics, M. Metz, A. Papoulis, R. Skerlj, J.D. Stepp, R.R. Wei, Implications of promiscuous Pim-1 kinase fragment inhibitor hydrophobic interactions for fragment-based drug design, J Med Chem, 55 (2012) 2641-2648.

[81] X. Wang, S. Magnuson, R. Pastor, E. Fan, H. Hu, V. Tsui, W. Deng, J. Murray, M. Steffek, H. Wallweber, J. Moffat, J. Drummond, G. Chan, E. Harstad, A.J. Ebens, Discovery of novel pyrazolo[1,5-a]pyrimidines as potent pan-Pim inhibitors by structure- and property-based drug design, Bioorg Med Chem Lett, 23 (2013) 3149-3153.

[82] S.D. Knight, N.D. Adams, J.L. Burgess, A.M. Chaudhari, M.G. Darcy, C.A. Donatelli, J.I. Luengo, K.A. Newlander, C.A. Parrish, L.H. Ridgers, M.A. Sarpong, S.J. Schmidt, G.S. Van Aller, J.D. Carson, M.A. Diamond, P.A. Elkins, C.M. Gardiner, E. Garver, S.A. Gilbert, R.R. Gontarek, J.R. Jackson, K.L. Kershner, L. Luo, K. Raha, C.S. Sherk, C.M. Sung, D. Sutton, P.J. Tummino, R.J. Wegrzyn, K.R. Auger, D. Dhanak, Discovery of GSK2126458, a Highly Potent Inhibitor of PI3K and the Mammalian Target of Rapamycin, ACS Med Chem Lett, 1 (2010) 39-43.

[83] A.C. Pierce, M. Jacobs, C. Stuver-Moody, Docking study yields four novel inhibitors of the protooncogene Pim-1 kinase, J Med Chem, 51 (2008) 1972-1975.

[84] M.S. Alphey, L. Pirrie, L.S. Torrie, W.A. Boulkeroua, M. Gardiner, A. Sarkar, M. Maringer, W. Oehlmann, R. Brenk, M.S. Scherman, M. McNeil, M. Rejzek, R.A. Field, M. Singh, D. Gray, N.J. Westwood, J.H. Naismith, Allosteric Competitive Inhibitors of the Glucose-1-phosphate Thymidylyltransferase (RmIA) from Pseudomonas aeruginosa, ACS Chemical Biology, 8 (2013) 387-396.

[85] K. Huber, L. Brault, O. Fedorov, C. Gasser, P. Filippakopoulos, A.N. Bullock, D. Fabbro, J. Trappe, J. Schwaller, S. Knapp, F. Bracher, 7,8-dichloro-1-oxo- $\beta$-carbolines as a versatile scaffold for the development of potent and selective kinase inhibitors with unusual binding modes, J Med Chem, 55 (2012) 403-413.

[86] L. Lama, C. Adura, W. Xie, D. Tomita, T. Kamei, V. Kuryavyi, T. Gogakos, J.I. Steinberg, M. Miller, L. RamosEspiritu, Y. Asano, S. Hashizume, J. Aida, T. Imaeda, R. Okamoto, A.J. Jennings, M. Michino, T. Kuroita, A. Stamford, P. Gao, P. Meinke, J.F. Glickman, D.J. Patel, T. Tuschl, Development of human cGAS-specific smallmolecule inhibitors for repression of dsDNA-triggered interferon expression, Nature Communications, 10 (2019) 2261.

[87] P.G. Wyatt, A.J. Woodhead, V. Berdini, J.A. Boulstridge, M.G. Carr, D.M. Cross, D.J. Davis, L.A. Devine, T.R. Early, R.E. Feltell, E.J. Lewis, R.L. McMenamin, E.F. Navarro, M.A. O'Brien, M. O'Reilly, M. Reule, G. Saxty, L.C. Seavers, D.M. Smith, M.S. Squires, G. Trewartha, M.T. Walker, A.J. Woolford, Identification of N-(4-piperidinyl)-4(2,6-dichlorobenzoylamino)-1H-pyrazole-3-carboxamide (AT7519), a novel cyclin dependent kinase inhibitor 
using fragment-based X-ray crystallography and structure based drug design, J Med Chem, 51 (2008) 49864999.

[88] R.A. Engh, A. Girod, V. Kinzel, R. Huber, D. Bossemeyer, Crystal structures of catalytic subunit of cAMPdependent protein kinase in complex with isoquinolinesulfonyl protein kinase inhibitors $\mathrm{H} 7, \mathrm{H} 8$, and $\mathrm{H} 89$. Structural implications for selectivity, J Biol Chem, 271 (1996) 26157-26164.

\section{Figures}<smiles>O=c1[nH]c(=O)n([C@H]2C[C@H](O)[C@@H](CO)O2)cc1F</smiles>

Floxuridine<smiles>Cc1cn([C@H]2C[C@H](N=[N+]=[N-])[C@@H](CO)O2)c(=O)[nH]c1=O</smiles>

Zidovudine<smiles>Nc1ccn(C2C[C@H](O)[C@@H](CO)OO2)c(=O)n1</smiles>

Cytarabine<smiles>O=c1nc[nH]c2c1ncn2[C@H]1CC[C@@H](CO)O1</smiles>

Didanosine<smiles>Nc1ncnc2c1ncn2[C@@H]1O[C@H](CO)[C@@H](O)[C@H]1O</smiles>

Vidarabine<smiles>Nc1ccn([C@H]2CC[C@@H](CO)O2)c(=O)n1</smiles>

$\mathrm{HO}$<smiles></smiles>

Zalcitabine<smiles>Nc1nc2c(ncn2COCCO)c(=O)[nH]1</smiles>

acyclovir

Stavudine

Figure 1

Drugs based on the modification of nucleosides ribose 
B

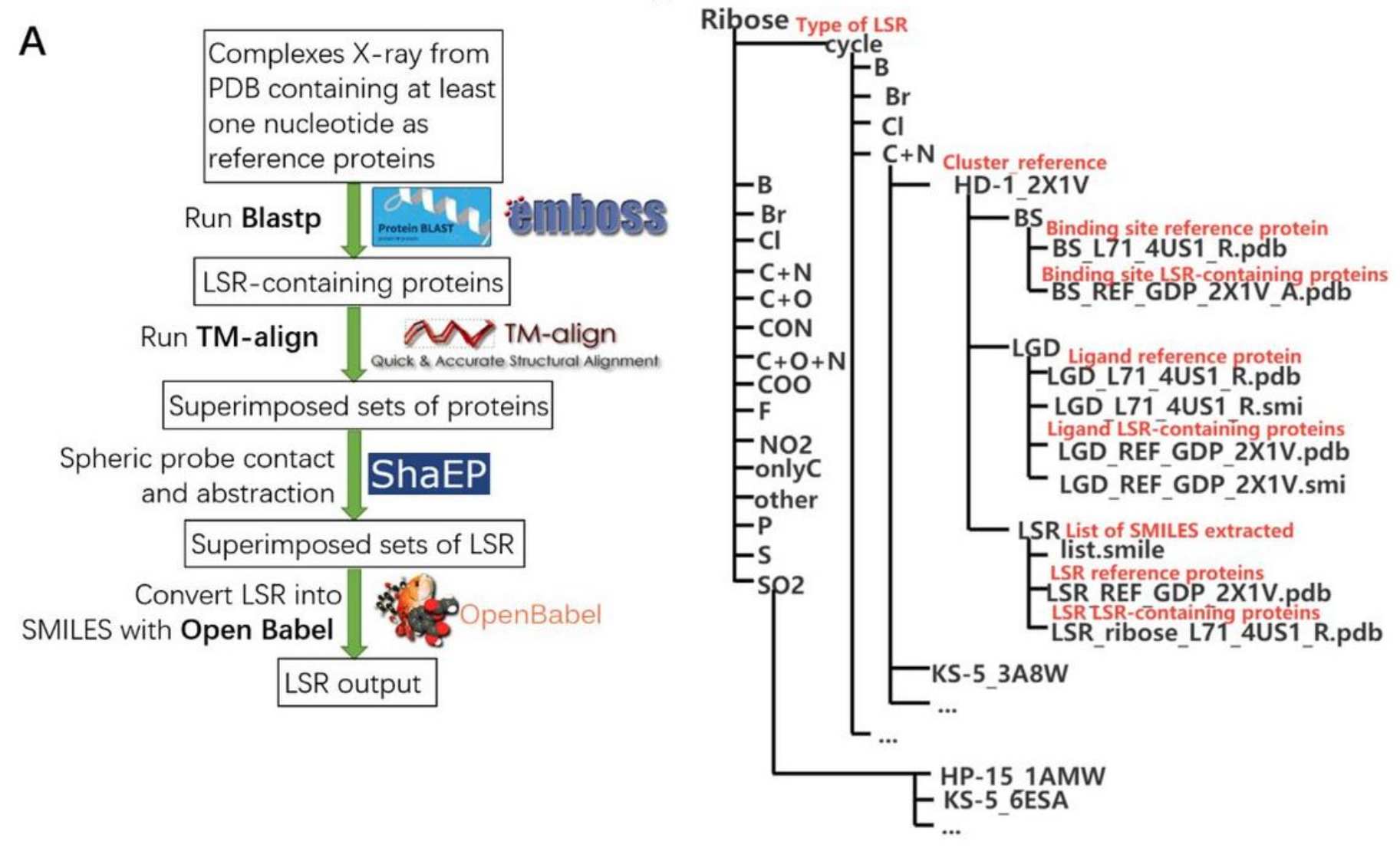

Figure 2

(A) Computational workflow. (B) The clustering graph of dataset. 
A

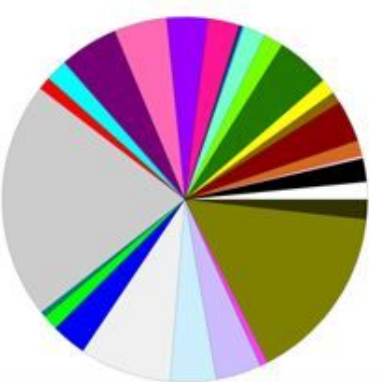

H:

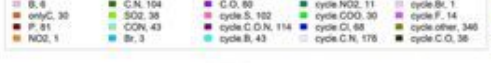

D

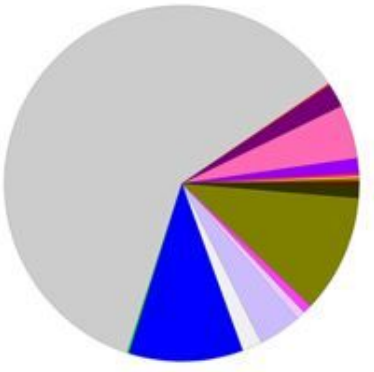

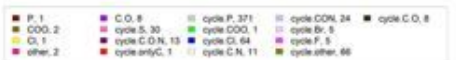

\section{G}

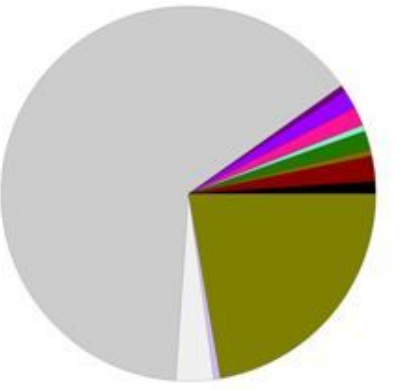

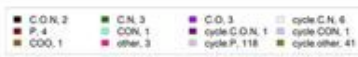

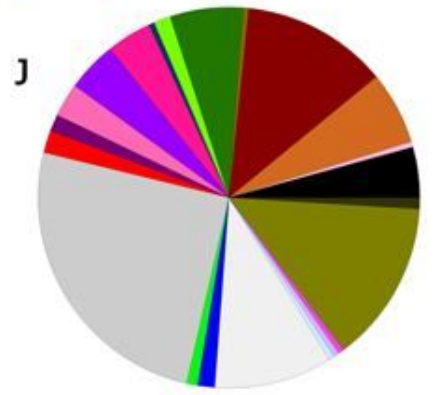

:

B

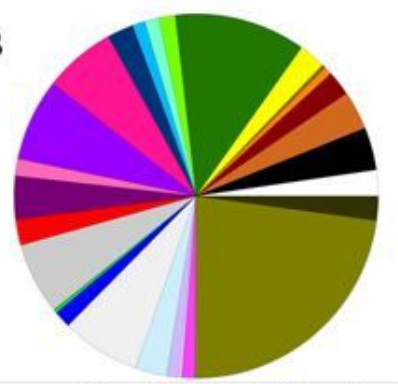

:

E

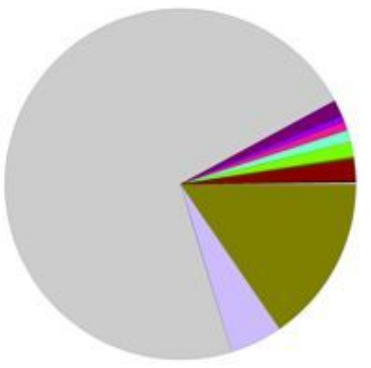

:

H

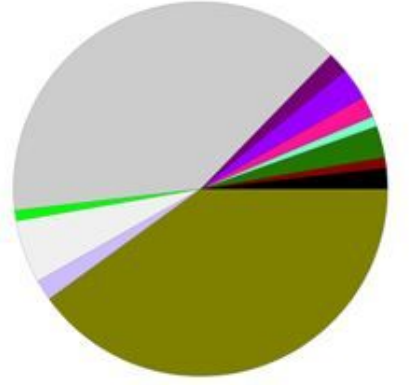

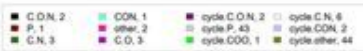

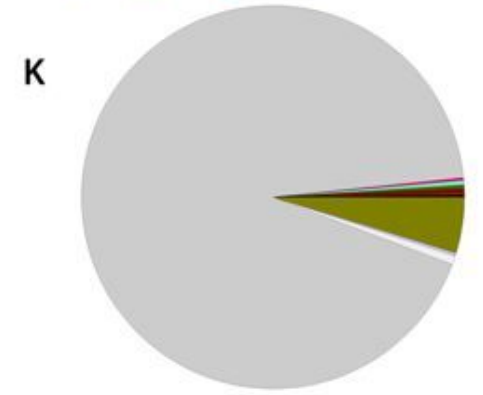

:
C

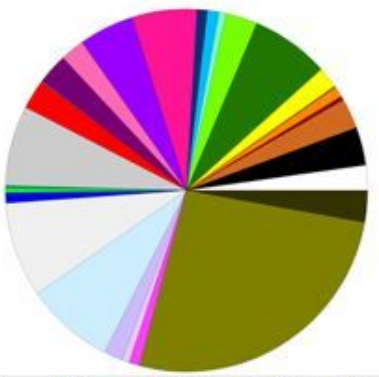

滀: 憡

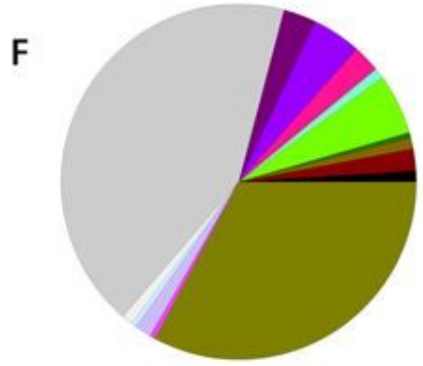

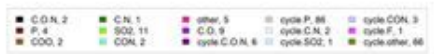

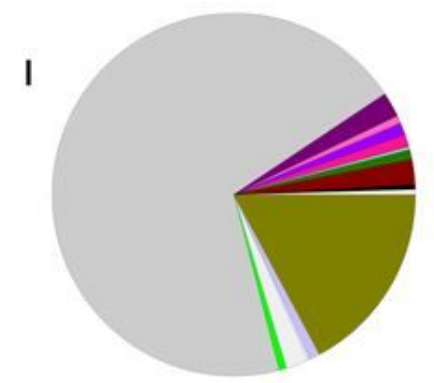

:

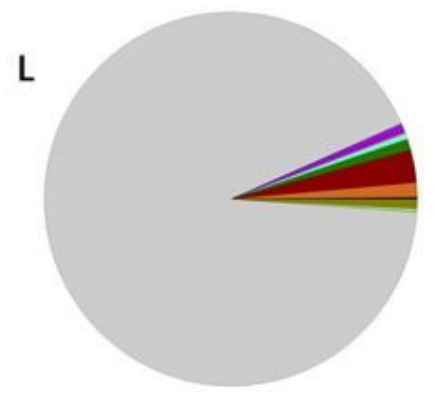

:

\section{Figure 3}

Distribution of the data set into categories assigned based on the SMILES codes of the structural isosteres of (A) AMP, (B) ADP, (C) ATP, (D) U5P, (E) UDP, (F) UTP, (G) C5P, (H) CDP, (I) CTP, (J) 5GP, (K) GDP, (L) GTP ribose. 

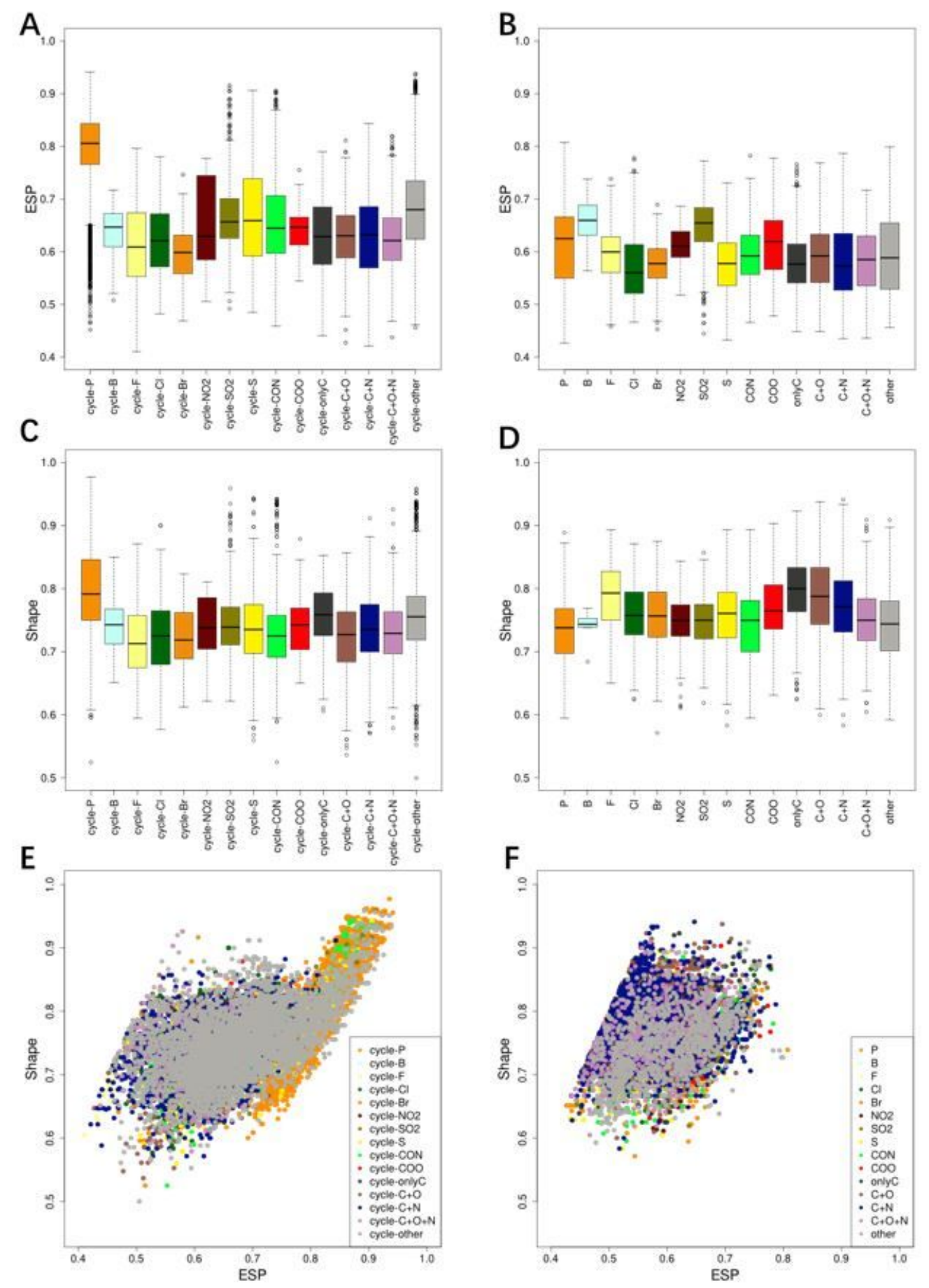

\section{Figure 4}

Segregation of the structural replacements according to their shape and electrostatic similarity scores compared to the reference ribose group calculated by ShaEP. (A, B) Boxplot of the electrostatic potential (ESP) overlap score for (A) cyclic and (B) noncyclic fragments. (C, D) Boxplots of shape overlap score for (C) cyclic or noncyclic (D) fragments. $(E, F)$ Scatterplots of these scores. 

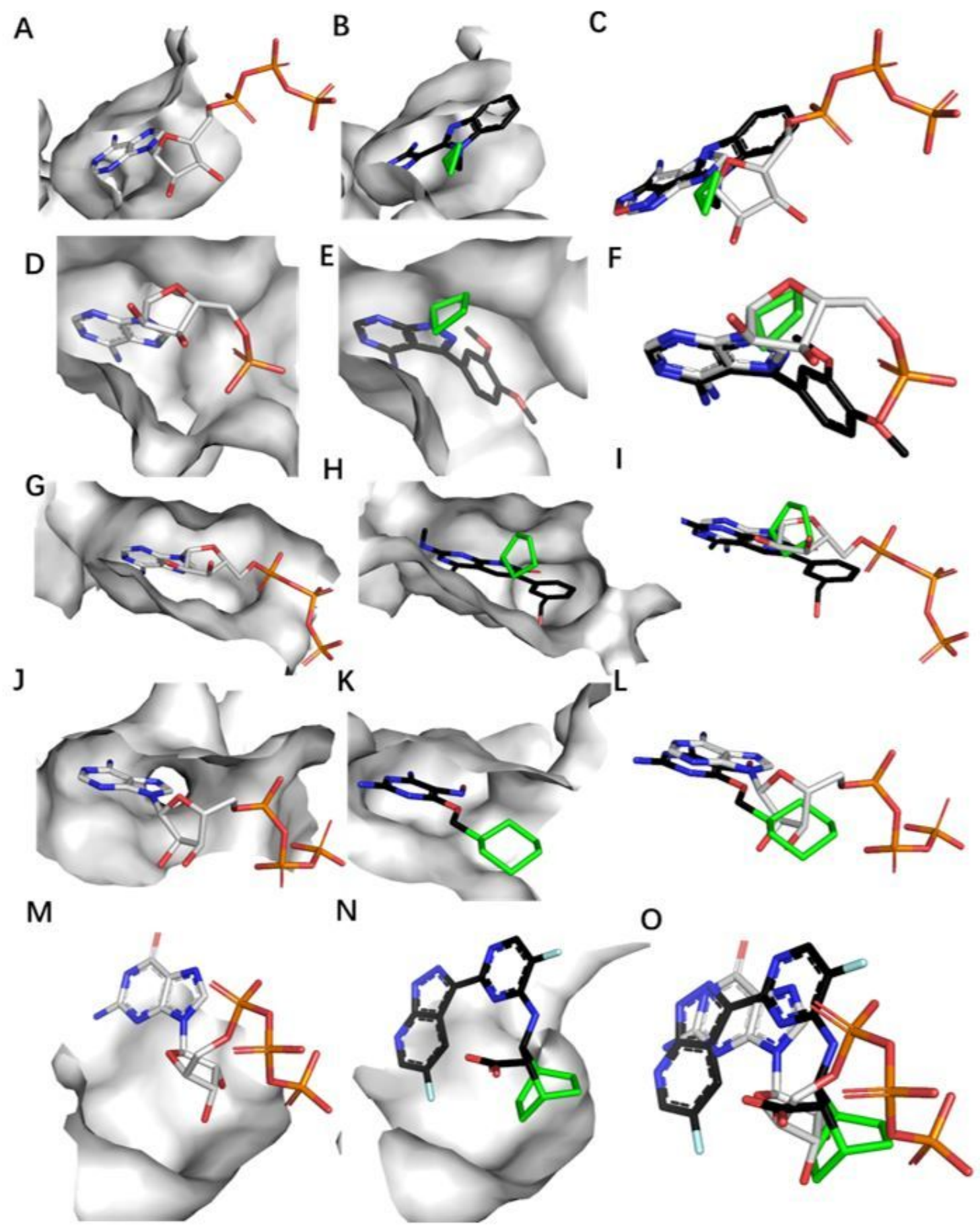

\section{Figure 5}

Selected examples of apolar aliphatic ring replacements of ribose. (A-C) Bos taurus S6 kinase, ligand Z09 (example 1, PDB codes 4C36 and 1Q24); (D-F) Homo sapiens c-Src kinase, ligand KS4 (example 2, PDB codes 3EN5 and 3DQX); (G-I) Homo sapiens phosphoinositide 3-kinase, ligand ML8 (example 3, PDB codes 3ML8 and 1E8X); (J-L) Homo sapiens cyclin dependent kinase 2, ligand NW1 (example 4, PDB codes 1E1X and 1B38). (M0) Influenza B virus polymerase basic protein 2, ligand BYB (example 5, PDB codes $6 E U X$ and 5EFC). (A, D, G, J, M) Reference proteins; $(B, E, H, K, N)$ structural isostere (carbon atom is in green, other part of carbon is in black) containing proteins; $(\mathrm{C}, \mathrm{F}, \mathrm{I}, \mathrm{L}, \mathrm{O})$ close-up view of the ligand superimposition. In this and following figures, the 
ligands are named according to their PDB 3-letter codes, the proteins are named according to PDB 4-letter codes. Putative hydrogen bonds, pi-pi staking interaction are shown as yellow dotted lines and distance is labelled. The carbon atom of ribose structural replacements in target ligand are highlighted in green while others are showed in black.
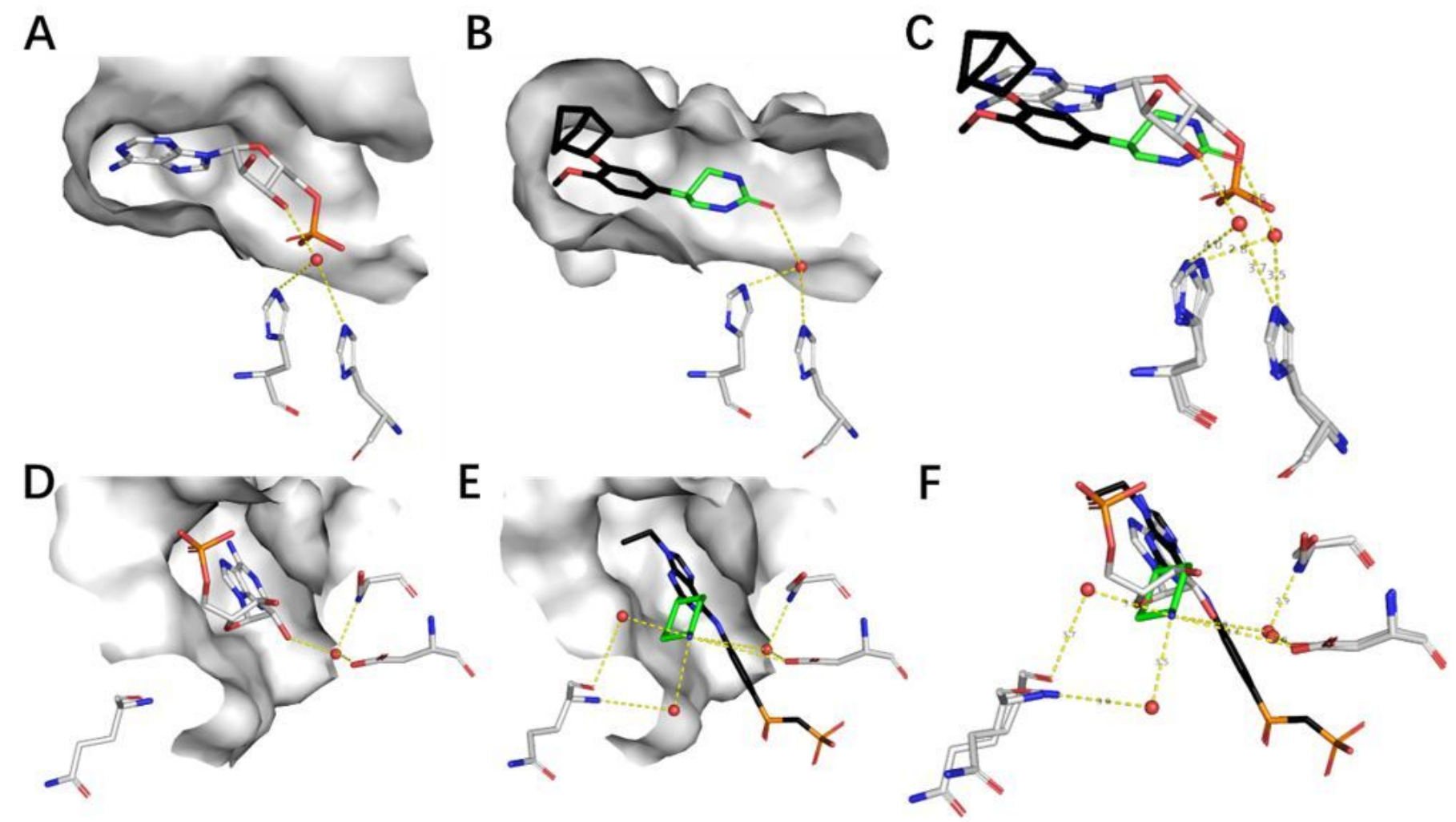

Figure 6

Selected examples of polar aliphatic ring replacements of ribose. $(A-C)$ Homo sapiens PDE4B, ligand OCP (example 5, PDB codes 3KKT and 1TB5). (D-F) Homo sapiens c-Src kinase, ligand 24A (example 6, PDB codes 2BDF and $3 \mathrm{DQX}) .(\mathrm{A}, \mathrm{D}$,$) Reference proteins; (\mathrm{B}, \mathrm{E})$ structural isostere (carbon atom is in green, other part of carbon is in black) containing proteins; (C, F) close-up view of the superimposition. 


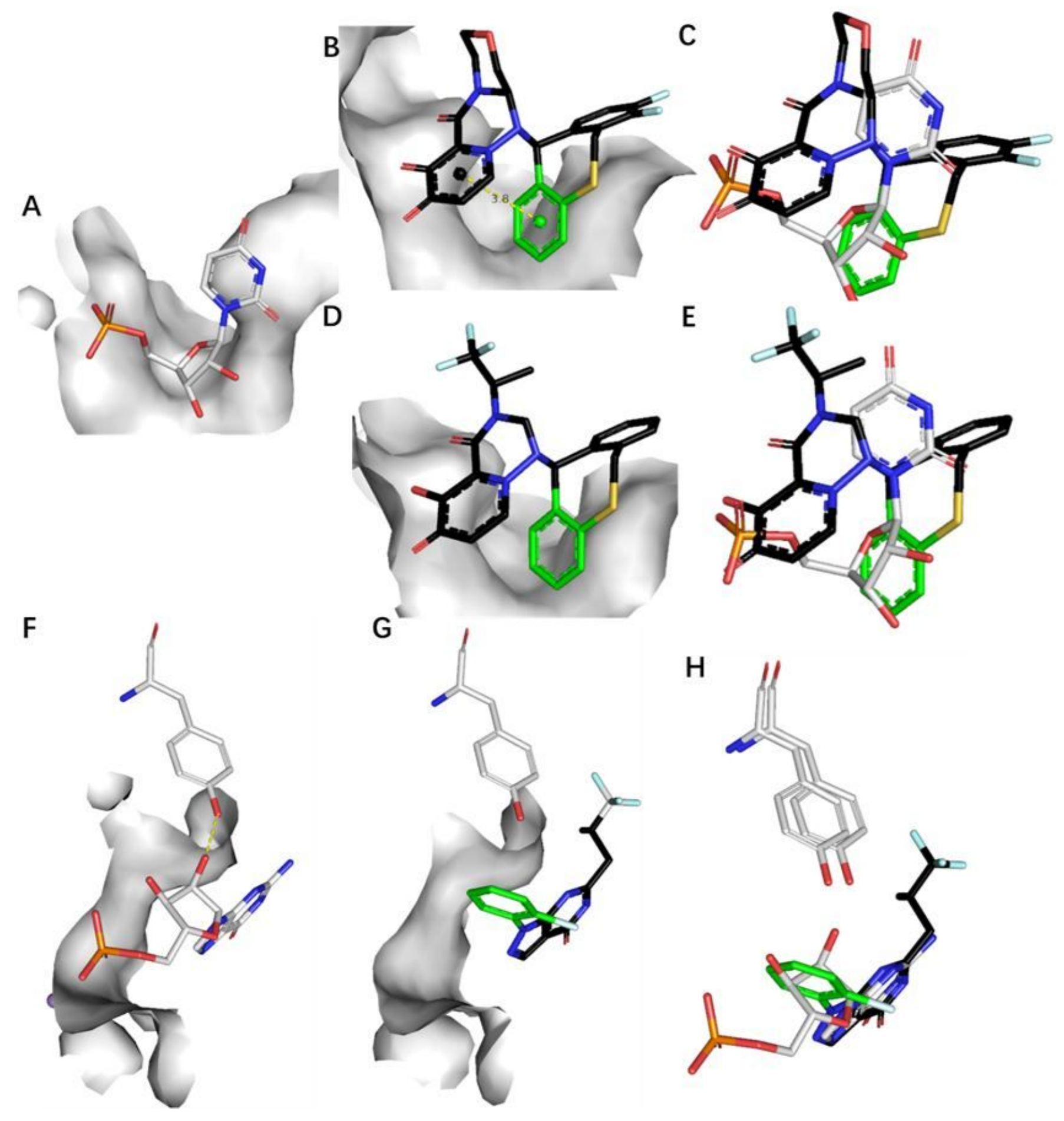

Figure 7

Selected examples of aromatic ring replacements of ribose. (A-C) Influenza A virus endonuclease, ligand $E 4 Z$ (example 7, PDB codes 6FS6 and 5DEB). (A, D, E) Influenza A virus endonuclease, ligand R07 (example 8, PDB codes 5VPT and 5DEB). ( $\mathrm{F}-\mathrm{H}$ ) Homo sapiens hydrolase, ligand BYE (example 7, PDB codes 3K3H and 3DY8). $(A, F)$ Reference proteins; $(B, D, G)$ structural isostere (carbon atom is in green, other part of carbon is in black) containing proteins; $(\mathrm{C}, \mathrm{E}, \mathrm{H})$ close-up view of the superimposition. 


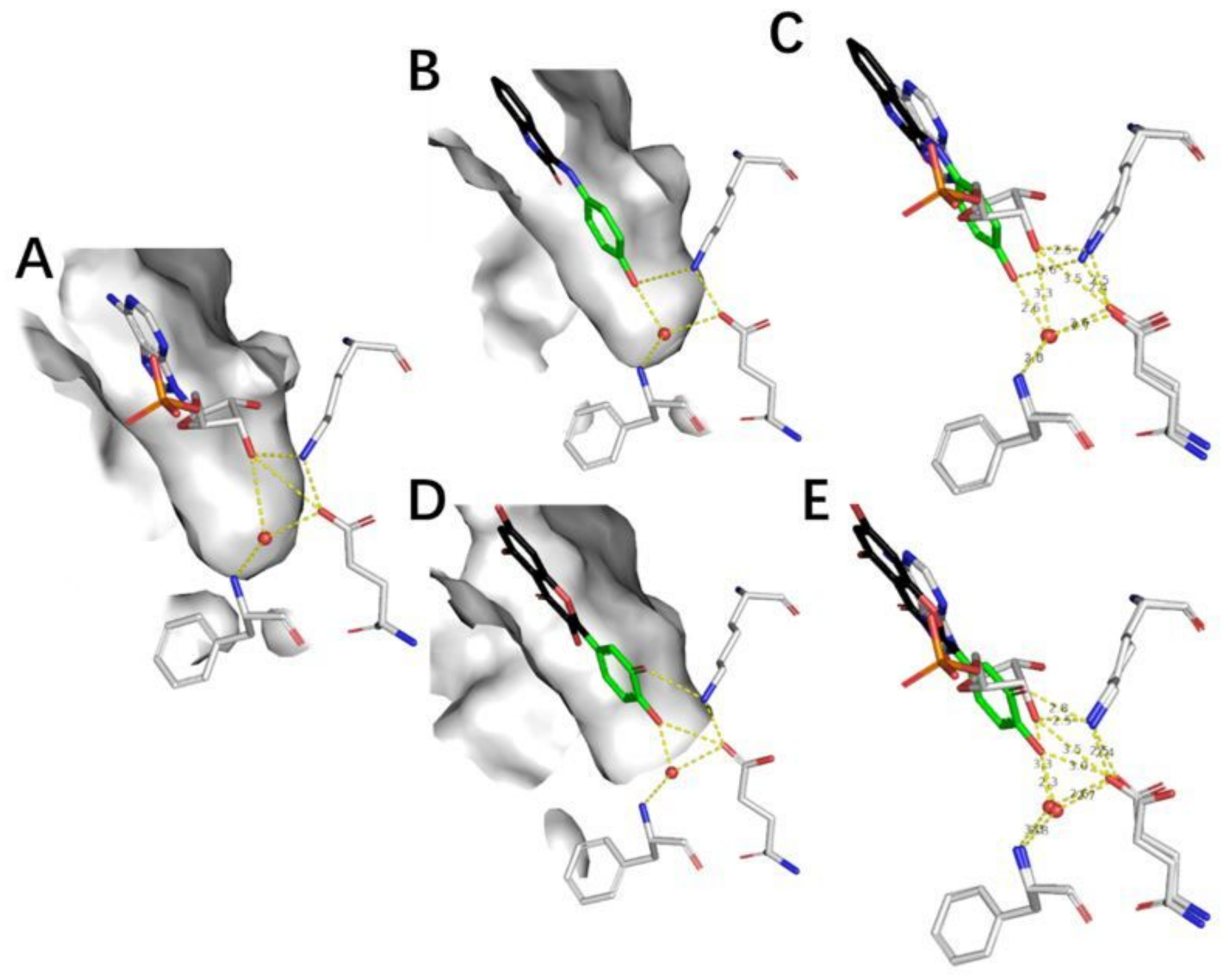

Figure 8

Selected examples of substituted aromatic ring replacements of ribose. (A-E) Homo sapiens kinase Pim1, ligand LI7(B, C), QUE (D, E) (example 10 and 11, PDB codes 1YXX and 4LMU). (A) Reference proteins; (B, D) structural isostere (green) containing proteins; $(C, E)$ close-up view of the superimposition. In this and following figures, the ligands are named according to their PDB 3-letter codes. 

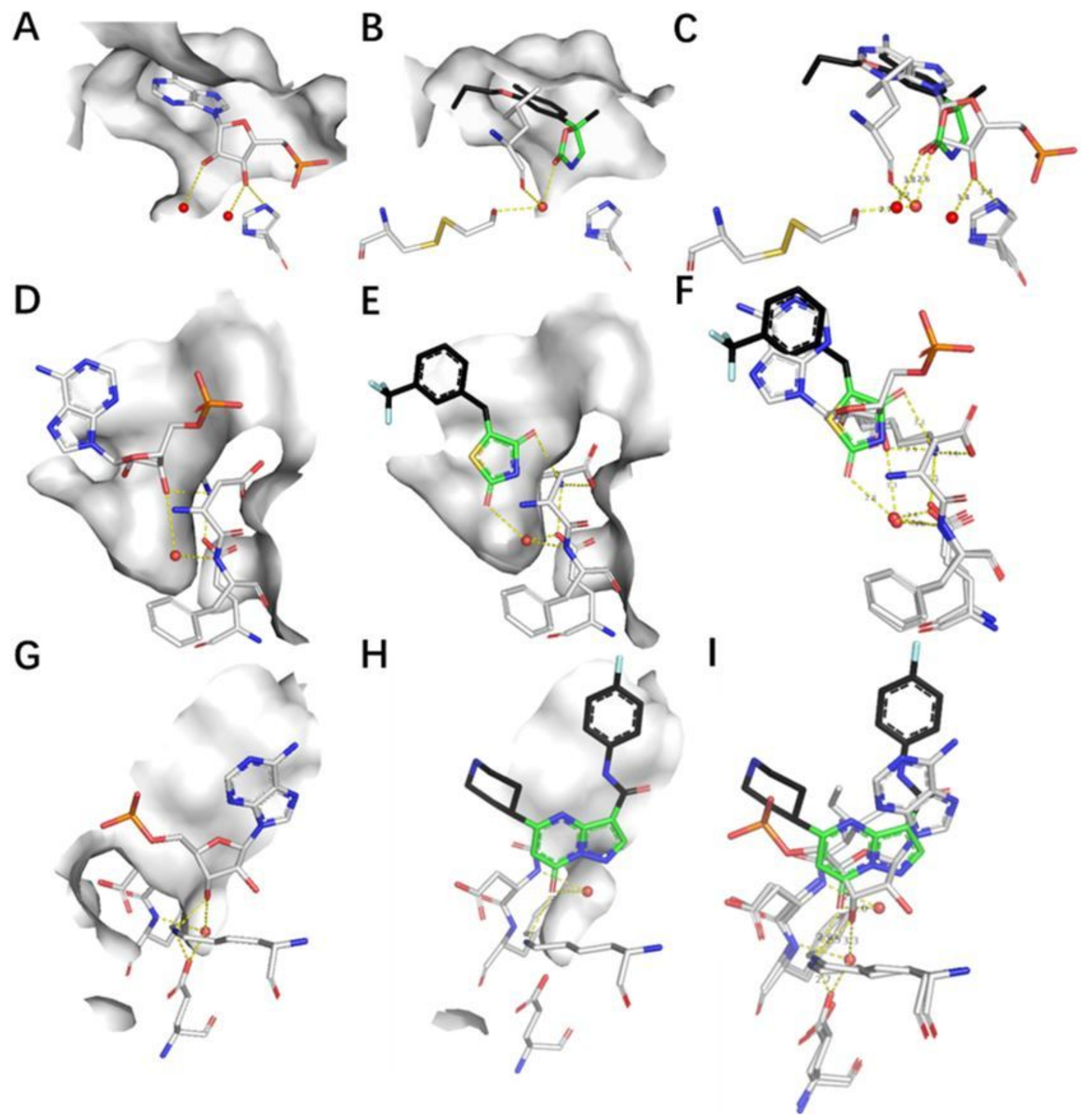

Figure 9

Selected examples of substituted heteroaromatic ring replacements of ribose. (A-C) Homo sapiens PDE4B, ligand 5RM (example 12, PDB codes 1XM6 and 1ROR); (D-F) Homo sapiens kinase Pim1, ligand OFS (example 13, 3VC4 and 1YXU); (G-I) Homo sapiens kinase Pim1, ligand 10A (example 14, 4KOY and 1YXU). (A, D, G) Reference proteins; (B, E, H) structural isostere (green) containing proteins; (C, F, I) close-up view of the superimposition. In this and following figures, the ligands are named according to their PDB 3-letter codes. 

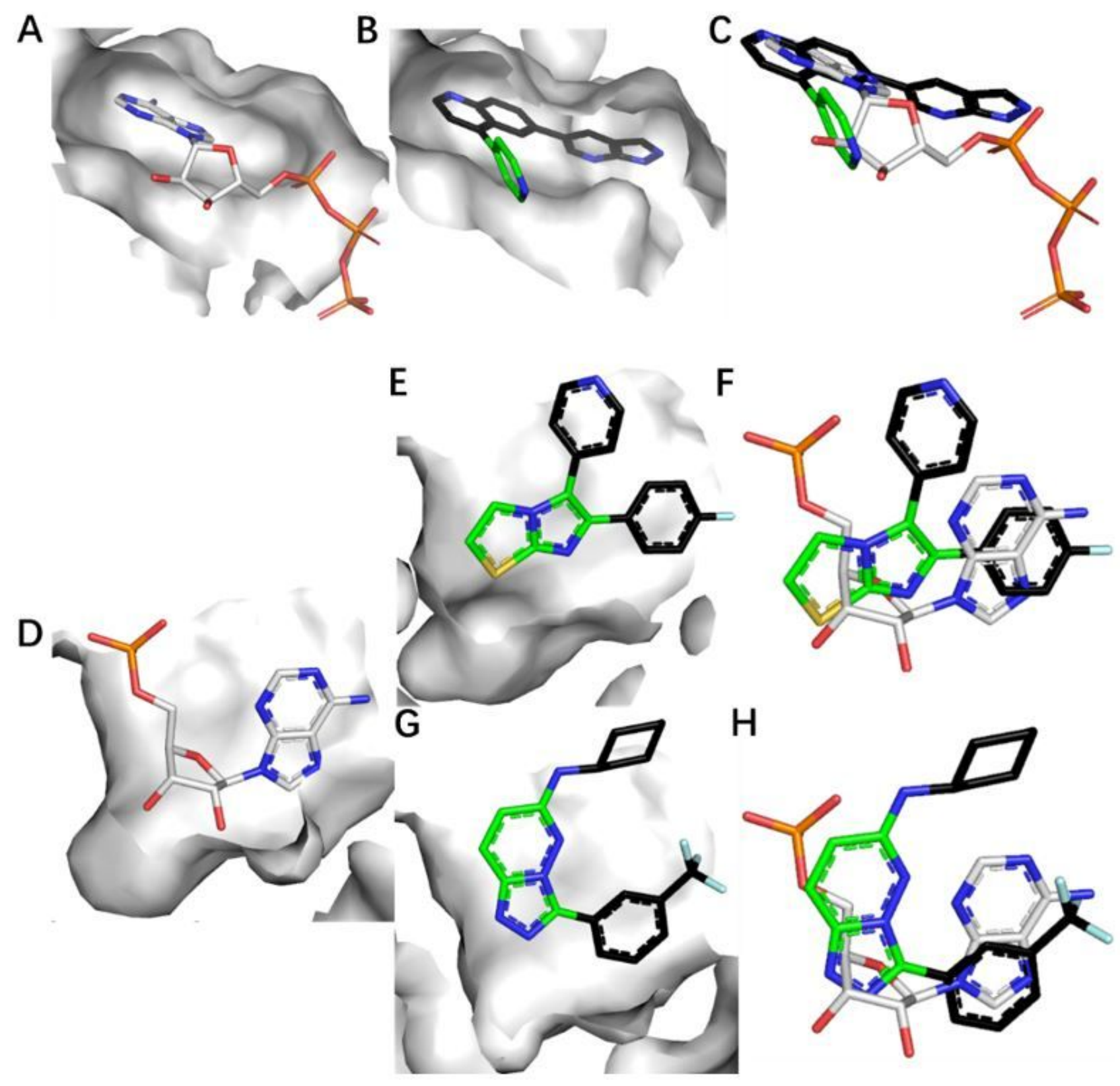

Figure 10

Selected examples of heteroaromatic rings ring replacements of ribose. (A-C) Homo sapiens kinase PI3, ligand LXX, (example 15, PDB codes 3L54 and 1E8X); (D-H) Homo sapiens kinase Pim1, ligand SK8 (E, F), VX2(G, H) (example 16 and 17, PDB codes 4LL5, 3BGQ and 1YXU). (A, D) Reference proteins; (B, E, G) structural isostere (green) containing proteins; $(C, F, H)$ close-up view of the superimposition. 

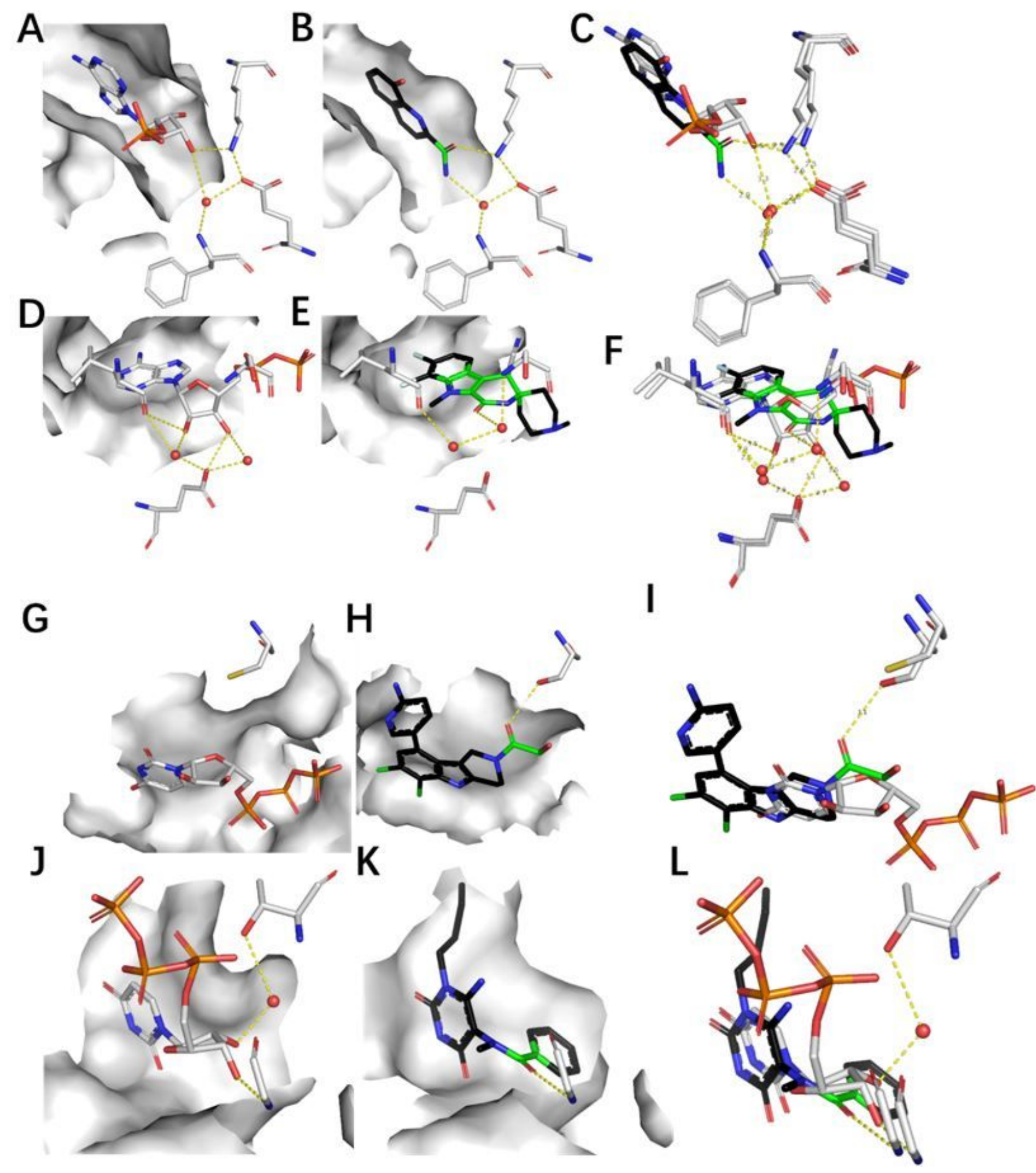

Figure 11

Selected examples of amide replacements of ribose. (A-C) Homo sapiens Pim-1 kinase, ligand 0FK, (example 18 PDB codes 3VBV and 1YXU); (D-F) Homo sapiens Death-associated protein kinase 3, ligand 7CP (example 19, PDB codes 3BHY and 2W4J). (A, D) Reference proteins; (B, E) structural isostere (green) containing proteins; (C, F) close-up view of the superimposition. In this and following figures, the ligands are named according to their PDB 3-letter codes. (G-I) Homo sapiens cyclic GMP-AMP synthase, ligand JUJ, (example 20 PDB codes 6MJW and 4JLZ); (J-L) Pseudomonas aeruginosa Glucose-1-phosphate thymidylyltransferase (RmIA), ligand 942, (example 21 PDB codes 4B42 and 4H09). 


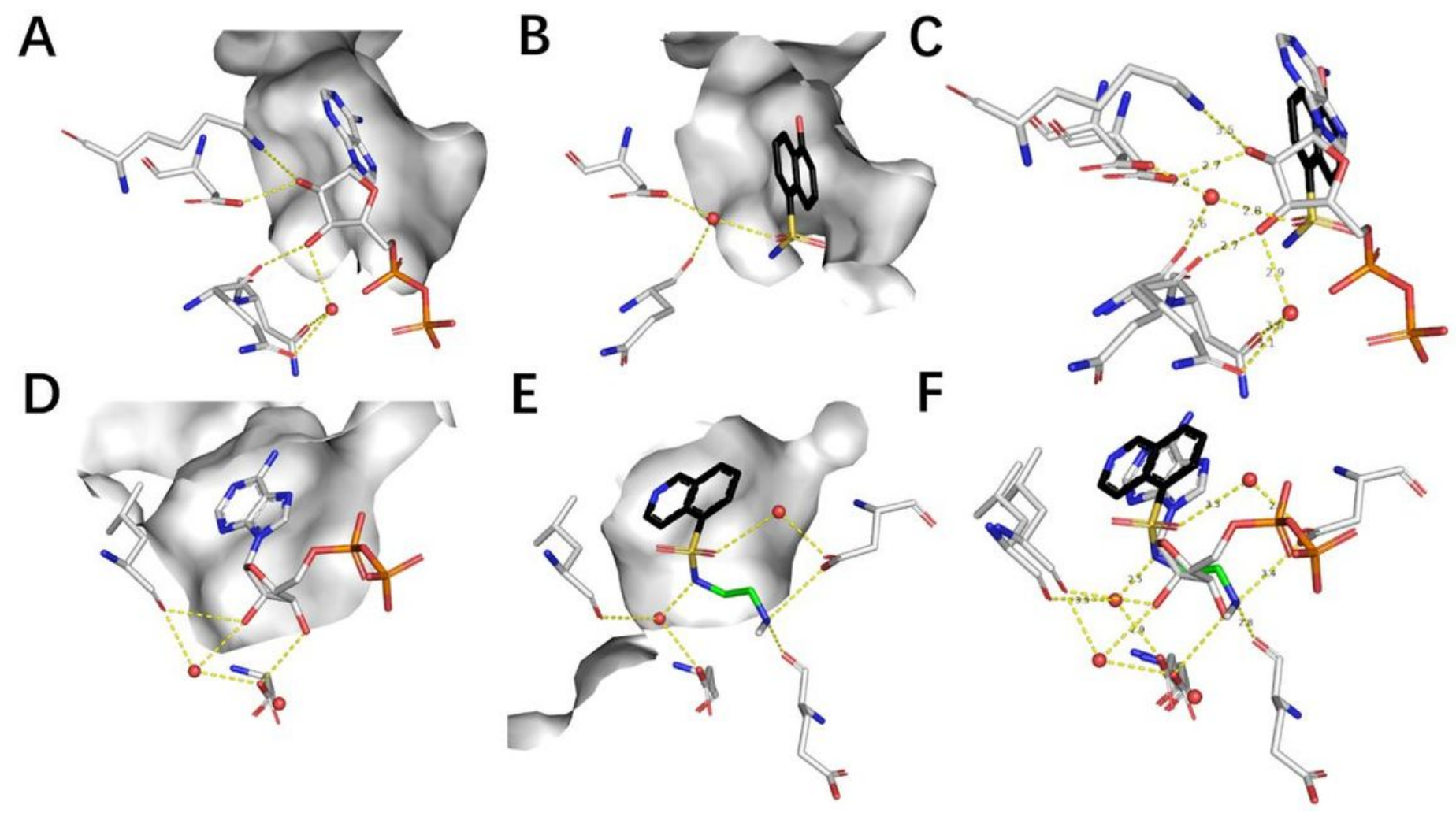

Figure 12

Selected examples of sulfonamide replacements of ribose. (A-C) Homo sapiens CAMP-dependent protein kinase, ligand LZ2, (example 22 PDB codes 2VTH and 4I3Z); (D-F) Bos taurus CAMP-dependent protein kinase, ligand IQS (example 23, PDB codes 1YDS and 1JBP). (A, D) Reference proteins; (B, E) structural isostere (green) containing proteins; $(\mathrm{C}, \mathrm{F})$ close-up view of the superimposition. In this and following figures, the ligands are named according to their PDB 3-letter codes. 